\title{
EFEITO DOS QUEBRA-VENTOS DE Greoillea robusta A. CUNN. SOBRE A VELOCIDADE DO VENTO
}

\author{
GISELDA DURIGAN
}

Orientador: Prof. Dr. JOAO WALTER SIMOEES

Dissertação apresentada à Escola Superior de Agricultura "Luiz de Queiroz", da Universidade de São

Paulo, para obtenção do título de

Mestre em Engenharia Florestal.

PIRACICA B A

Estado de São Paulo - Brasil Junho $=1986$ 
Dedico

a meu pai, que me ensinou a terminar tudo que houvesse começado. 


\section{AGRADECIMENTOS}

Quero expressar o meu agradecimento a todas as pessoas que colaboraram na execução deste trabalho, especialmente:

- ao Prof. Dr. João Walter Simões, pela orientação;

- ao Prof. Dr. José Carlos Ometto, pelas sugestões que dirigiram a pesquisa;

- ao Dr. Alceu de Arruda Veiga, pelas sugestões apresentadas;

- ao Prof. Paulo Yoshio Kageyama, pelo estimulo a prosseguir por um novo caminho;

- à Sra. Dirce Alessi Pelegrino, pela compreensão de minhas falhas;

- aos Engos. Agrônomos Paulo Roberto de Guerra Carvalho e Otávio E. de Souza Dias, pelo apoio necessärio aos trabalhos de campo;

- aos Srs. Celso Fernandes, Hermann de Morais Barros e Hélio Cândido de Souza Dias, proprietários das fazendas onde for am executados os trabathos de carpo;

- à CAPES - Coordenação de Aperfeiçoamento de Pessoal de Nîvel superior, pela bolsa concedida nos anos de 1980 e 1981;

- Ao PqC VI Marco Antônio de Oliveira Garrido, pelo apoio durante a elaboração do trabalho;

- ao Wick, Luzia, Francisco e Sr. Nelson, pela ajuda nas mediçōes e amos tragens de carmo;

- à Fazenda Canadā, que cedeu funcionārios e laboratório para determinação da umidade das amostras de solo;

- ao Departamento de Física e Meteorologia, que forneceu os anemônetros para estudo do vento;

- à Ieda M. do A. Gurgel Garrido, pela ajuda nas anālises estatísticas dos resultados; 
- ao Luis, da biblioteca, sertpre disposto a ajudar na busca de material bibliográfico;

- à Marialice, pela correção das referências bibliográficas, e

- à Magalî, pela datilografia definitiva do trabalho. 


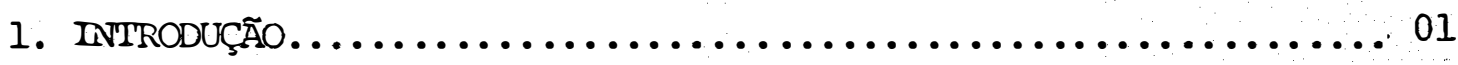

2. REVISÃO BIBLIOGRAFICA.......................... 03

2.1. Definição de quebra-ventos...................... 03

2.2. Histórico................................ 04

2.3. Características e ação do vento................... 07

2.4. Efeitos dos quebra-ventos....................... 08

2.4.1. Efeitos diretos dos quebra-ventos............. 09

2.4.2. Efeitos indiretos dos quebra-ventos sobre o microclima................................. 15

2.4.3. Efeitos indiretos dos quebra-ventos sobre o solo.. 18

2.4.4. Efeitos indiretos dos quebra-ventos sobre a cultura.................................... 20

2.5. Usos dos quebra-ventos........................ 23

2.5.1. Proteção contra a erosão eólica............... 23

2.5.2. Redução da evapotranspiração................ 23

2.5.3. Proteção contra doenças e danos mecânicos........ 24

2.5.4. Retenção e distribuição da neve.............. 24

2.5.5. Proteção das pastagens e do gado............... 24

2.5.6. outros usos.......................... ${ }^{25}$

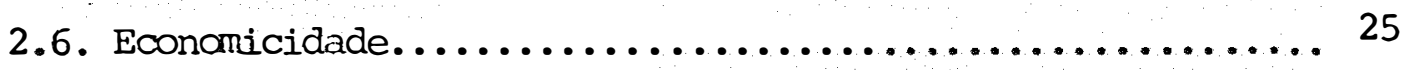

2.7. Casos de aumento de produtividade................ 27

2.8. Estrutura dos quebra-ventos.................... 29

2.8.1. Altura.............................. 29

2.8.2. Permeabilidade......................... 30

2.8.3. Orientação............................. 31

2.8.4. Fonna do pexfil e número de linhas............ 32

2.8.5. Extensão............................ 33

2.8.6. Distância entre linhas.................... 35 
2.9. Tipos de quebratventos......................... 35

2.10. Espécies............................... 36

2.11. Grevillea robusta A. Cunn..................... 38

3. MATERTAL E METODOS............................ 40

3.1. Local................................... 40

3.2. Pontos de mediçãn............................. 42

3.3. Caracterização dos quebra-ventos................. 42

3.4. Medições de velocidade do vento...................... 43

3.5. Medições de unidade do solo..........................44 44

3.6. Mediçães de produção de café........................ 44

4. RESULTADOS E DISCUSSÃO ........................... 46

4.1. Caracterização dos quebra-ventos.................. 46

- 4.2. Velocidade do vento............................ 48

4.3. Competição por luz........................... 50

4.4. Unidade do solo............................... 51

4.5. Produção de café............................... 54

4.6. Implantação e manejo dos quebra-ventos............... 56

5. CONCLUSర̈ES.................................... 58

6. IITERATURA CITADA............................ 60

7. APENDICE.................................. 70 
EFEITO DOS QUEBRA-VENTOS DE Grevillea robusta A. CUNiN. SOBRE A VELOCIDADE DO VENTO

GISELDA DURIGAN

Orientador: Prof. Dr. João Walter Simões

RESUMO

Os quebra-ventos de Grevillea robusta A. Cunn. vêm sendo utilizados há algum tempo para proteger lavouras de café no Brasil, especialmente no norte do Paraná.

Para avaliar o comportamento desta espécie como quebravento estudaram-se cinoo barreiras de diferentes caracteristicas, no tocante aos efeitos sobre a velocidade do vento e alguns aspectos relativos à umidade do solo e à produção de café em presença de quebra-ventos. concluiu-se que há um efeito benéfico, mais intenso na faixa compreendi da entre 4 e $8 \mathrm{H}$ (múltiplos da altura da barreira), que compensa as perdas decorrentes da competição das árvores com a cultura na faixa mais próxima à barreira. Em relação à estrutura do quebra-vento, verificou se que a melhor proteção é obtida quando a porosidade é homogênea, com . - mínimo de espaços vazios entre as árvores. Uma única linha de árvores de Grevillea robusta, espaçadas em $5 \mathrm{~m}$ entre si, sem desrama, forneceu a melhor proteção.

Para quebra-ventos em série, a distância máxima entre duas barreiras consecutivas não deve ultrapassar $200 \mathrm{~m}$. 
EFFECTS OF Grevillea robusta A. CUNN. WINDBREAKS ON WIND VELOCITY

GISELDA DURIGAN

Adviser: Prof. Dr. João Walter Simões

\section{SUMMARY}

Windbreaks of Grevillea robusta A. Cunn. are being used in Brazil to protect coffee tillage, specially in Parana state.

In order to avaliate the performance of this species like windbreaks, it was studied five different barriers, and its effects on wind velocity and some aspects of soil moisture and coffee production.

It was concluded that there is a very good effect between 4 and $8 \mathrm{H}$ (multiples of barrier height). This effect overcomes losses be cause of competition close to the tries, making windbreak use compensati. ve.

The best protection was obtained with barriers of homogeneous pemeability, without "gaps" among the trees. Only one row of Grevillea robusta, $5 \mathrm{~m}$ spaced, without pruning, gives the best protection When windoreaks are planted in series, the distance between consecutive barriers could not exceed $200 \mathrm{~m}$. 
1- INIRODUÇÃO

"Um dos grandes problemas tanto na nossa agricultura como da nossa economia ê o baixo crescimento da produtividade agrỉcola; a produção eleva-se... à custa de uma crescente apropriação de terras devolutas, da expansão da fronteira agrícola e da destruição, em larga escala, de recursos naturais renovāveis e não renováveis - floresta, fauna e solos... Esse crescimento horizontal traz una sërie de problemas, pois requer a agregação de novas terras à cultura, provocando a expansão das estruturas de apoio - estradas, comunicaçẽes, serviços de saúde, de educa ção, etc. - que redundam em investimentos püblicos quase sempre sam retorno ou com retorno a longo prazo". (ANDRADE, 1979)

Esse aumento da produção baseado no alargamento das areas cultivadas tem limites. Tem limites sob o aspecto econômico, quando o valor da terra se torna alto demais, e sob o aspecto geográfico, can o esgotamento das áreas de solos cuja fertilidade permite utilização agrïcola ou pecuária.

Nas regiões sul e sudeste do pais e em parte do centro-ceste, ambos os limites já foram atingidos. As terras cultivāveis estão to- 
talmente ocupadas e o valor da terra é tão alto que impossibilita a expansão das propriedades, além de tornar anti-econômicas as culturas de baixa produtividade.

Diante deste quadro e do aumento constante da demanda de alimentos, só resta uma saída: aumentar a produtividade agrícola. Toda tentativa neste sentido é vâlida e toda técnica alternativa que possa trazer aumento da produção sem expansão da área deve ser incentivada e divulgada.

Surgem assim os quebra-ventos corro uma opção. Utilizados desde o século passado en paìses que se defrontaram com a questão da queda de produtividade e da destruição dos recursos naturais hã muito tempo, os quebra-ventos têm se mostrado camo uma técnica excelente, meIhorando as condições ambientais e trazendo aumento da produçāo por unidade de área, alêtr de muitas vezes melhorar a qualidade do produto.

No Brasil, o uso de quebra-ventos é recente e tem se restringido quase que exclusivamente à lavoura cafeeira de são Paulo e,prin cipalmente, do norte do Paraná.

Algumas espécies de ärvores têm sido utilizadas, com predo minância absoluta da Grevillea robusta A. Cunn., recomendada pelo IBC (Instituto Brasileiro do Café).

- objetivo desta pesquisa é analisar as características e - camportamento desta espécie camo quebra-vento, com base no estudo das modificações que as barreiras de Grevillea provocam no fluxo do vento. 


\section{2- REVISÃO BIBLIOGRAFICA}

\subsection{Definição de quebra-ventos. .}

No início do século, um quebra-vento era definido camo um simples objeto que serve de obstăculo aos ventos de superfĩcie (BATES, 1911).

A medida que a utilização foi se estendendo e os efeitos se tornaram mais claros, a definição foi se modificando e se confundindo com estes efeitos e com os benefícios esperados. Assim, GOITTA (1956) define quebra-ventos como "artifícios destinados a deter ou, pelo menos, diminuir a ação erosiva dos ventos fortes sobre as terras de textura leve, as culturas e, principalmente, os pomares". IBARRA (s.d.l define-os como "estruturas constuuỉdas con árvores e arbustos plantados de forma perpendicular aos ventos dominantes e que cumpren a função de fazer diminuir a velœidade do vento e evitar danos às plantas por efeito da erosão eólica e dessecação do solo".

De una maneira sucinta e clara O IBC (1981). define os quebra-ventos arbóreos como barreiras constituídas de renques de ärvores dis postos em direção perpendicular aos ventos dominates. 
Os quebra-ventos a que se refere este trabalho podem ser de finidos simplesmente como barreiras arbóreas destinadas a reduzir a velocidade do vento e os danos que ele pode causar às culturas agrícolas.

\subsection{Histórico}

- Embora os trabalhos mais antigos localizados tenham sido es critos nOs EUA (CARD, 1897, e BATES, 1911), as referências históricas ao início da utilização de barreiras arbóreas indicam que paîses da Europa e da Âsia foram os pioneiros nesta técnica, embora não haja um consenso sobre isto.

GUYOT (1963) afirma que os primeiros quebra-ventos foram implantados na Escócia no séc. XVIII, para proteger as zonas litorâneas de ventos violentos e, no séc.: XIX, na Inglaterra, para proteger e melhorar culturas agrïcolas e, a partir destes exerplos, a técnica espaIhou-se por toda a Europa ainda no séc. XIX.

Por outro lado, KUMERLY (1974) afirma que "os russos foram os primeiros que, já em princỉpios do séc. XIX, plantaram faixas de bosque para a proteção contra o vento nas zonas de estepe e deserto da Ásia central, conseguindo com eles êxitos assombrosos".

A despeito da ampla utilização, a pesquisa, embora abundante, carecia de profundidade. BATES, en 1911, publicou nos EUA um trabaltho tão abrangente sobre quebra-ventos que, ainda hoje, è bibliografia básica sobre o assunto. Nessa época, segundo o autor, os quebra-ventos eram usados na França, para contenção de dunas, na Rússia, para proteger contra os ventos secos e nos EUA para valorizar esteticamente as propriedades, conter a erosão eólica e o amontoamento de neve, e para proteger pomares e pastagens.

No entanto, os quebra-ventos só foram implantados em escala nacional, com grande repercussão, na URSS, nos EUA e na Dinamarca, que são, hoje, os países mais avançados na pesquisa sobre o assunto.

Para GUYOT (1963) estes paỉses têm uma característica 
en conum: possuíam vastas extensōes de terras desprovidas de ärvores. A necessidade de quebra-ventos se fez sentir quando a agricultura avano̧ou sobre essas terras ou quando a umidade era o fator limitante.

Na URSS, o fator que levou à implantação de quebra-ventos foi a sucessão de catāstrofes agrỉcolas que ocorreram entre 1885 e 1950 , nas regiōes de solos de altissima fertilidade (chernozens) das estepes meridionais. Além dos ventos persistentes, a seca atingiu 20 vezes uma mesma região neste período. Na busca de solução para o problema, acabaram por encontrar nos quebra-ventos a melhor opção.

Em 1931, a URSS criou um organismo (Vnialmi) especialmente para estudar os quebra-ventos (GUYOT, 1963), enquanto os EUA desenvolviarn suas pesquisas sobre o assunto através do seu Departamento de Agricul tura (VAN DEUSEN, 1978).

Até 1930, apesar das pesquisas existentes e da divulgação de sua utilidade, os quebra-ventos não eram uma técnica commente adotada pelos agricultores nos EUA. Foi então que, entre 1935 e 1942, durante a grande depressão dos anos 30, houve uma explosão na implantação de barreiras arböreas, que veio a ser um marco decisivo na história dos que bra-ventos e dos prōprios EUA.

A depressão econômica coincidiu com os chamados "dust storms", que culminaram can o "Dust Bowl", en 1934. Neste ano, toneladas e toneladas de solo fértil foram levantadas pelo vento, formando uma imensa nuvem de poeira sobre as Grandes Planícies, que era visivel até na costa leste dos EUA. Eram tão comms nessa época as tempestades de pó que a década de 30 passou a ser chamada "the dirty thirties" ( POTTER, 1976).

Movido pela opinião püblica e pela crise econônica, e vendo que a produção agrìcola decaía corno consequlencia da erosão do solo, o presidente Franklin Roosevelt decidiu plantar quebra-ventos. Assim foi estabelecido um programa de plantio denominado "Prairie States Forestry Project", dirigido pelo Serviço Florestal dos EUA (GRIFFITH, 1976). Foram plantarias mais de 200 milhões de árvores e arbustos, en 30.000 pro- 
priedades. Os quebra-ventos totalizavam $29.760 \mathrm{~km}$ de extensão, desde o limite com o Canadá, até o Texas.

Inicialmente denominado "Shelterbelt Project", o programa atingiu uma área de $160 \mathrm{~km}$ de largura por $1840 \mathrm{Km}$ de extensão, de norte a sul dos EUA (POITIER, 1976).

Hoje, meio século após esta implantação em massa, os quebra-ventos estão sendo eliminados em algumas propriedades. A eliminação tem sido justificada, segundo GRIFFITH (1976), pela ampliação da área cultivada e, principalmente, pelos projetos de irrigação com pivô central. Com certeza, os "dirty thirties" não foram vividos por estes agri cultores que hoje estão derrubando as árvores que protegem suas lavouras dos danos causados pelo vento.

No Brasil, CAMARGO (1960) foi o primeiro a sugerir a utilização de quebra-ventos, recomendando que "os espigões planos, acima dos cafezais, devem ser deixados com mata alta ou cultivados com Eucalyptus, pinus ou outra essência cultivada de porte alto. Em caso de ser necessārio cortar a mata do espigão, deve-se deixar sempre um renque protetor, bem fechado, na marger da mata, acima do cafezal".

No entanto, apenas a partir de 1975, com o estouro dos preços do café após a geada, os agricultores brasileiros passaram a aprimorar as técnicas de cultivo visando o aumento da produtividade. Nessa época o IBC já recomendava a proteção dos cafezais por quebra-ventos de Grevillea robusta (BAGGIO, 1983). A partir de então, a paisagem do norte do Paraná se modificou, cortada por linhas de ärvores perpendiculares à dire ção do vento.

Por volta de 1980, com os preços do café em baixa, alguns agricultores arrancaram seus cafezais, substituindo-os pelo trigo e pela soja e, em algumas propriedades, atē os quebra-ventos foram eliminados , por ccuparem espaço e dificultarem a mecanização.

Hoje, com o café novamente em alta, em decorrência da seca, os quebra-ventos voltam a ser plantados, discutidos e recomendados. 


\subsection{Características e ação do vento-}

o vento pode ser definido simplesmente como massa de ar em movimento.

Interferir no fluxo do vento através do uso de quebra-ventos é fazer com que essa massa de ar passe a ter características e movimentação diferentes daquelas que apresenta em campo aberto, e estas alterações podem ser benēficas ou não, conforme as características do vento e da cultura a ser protegida.

Segundo OMETIO e CARAMORI (1981), para compreensão da atua ção do vento, é necessário conhecer as suas características, sendo as mais importantes:

a) Quantidade de movimento (nv) - é a energia associada ao produto da massa de ar pela velocidade desta massa. A transferência desta energia para os obstáculos que se encontram diante do vento (plantas, animais, solo,etc.), resulta na ação mecânica do vento, que compreende benefícios como aumento da polinização, moderação no fluxo de $\mathrm{CO}_{2}$, estínulo à quebra de gradiente de unidade e tem peratura no perfil da cultura, ou efeitos deletérios pa ra a cultura, como a quebra de galhos, derrubada de flo res, acamamento e até arrancamento de plantas.

Alếm dessa ação direta, a massa de ar em movirnento pode propiciar o ataque de pragas e doenças e provocar a ero são eólica, que é prejudicial à cultura pela redução da fertilidade do solo e também pelos danos que as partículas sólidas transportadas pelo vento podem provocar na superfície foliar.

b) Energia interna-expressa pela temperatura da massa de ar. Temperaturas adequadas podem estimular a evapotranspiração cuticular e estomática em níveis desejāveis para determinada cultura, regulando a fotossíntese e a respiração. Mas o vento pode ser frio demais, e pre 
judicar os processos fisiológicos da planta ou excessiva mente quente, provocando rápida perda de água por evapotranspiraçã̃o e outros distūrbios fisiológicos igualmente prejudiciais.

c) Umidade absoluta - corresponde à quantidade de vapor d'água contido por metro cúbico de ar, que è maior quanto maior a temperatura da massa de ar. A umidade ligeiramente alta beneficia a planta, dando condições para as atividades metabólicas, mas pode ser prejudicial quando for muito baixa, provocando evapotranspiração excessiva e até seca temporária da planta, e tambén quando for muito elevada, favorecendo a ocorrência de doenças.

\subsection{Efeitos dos muebra-ventos}

Os quebra-ventos agem diretamente sobre o ambiente

de trềs maneiras: sombreando parcial e temporarianente a cultura, absorvendo âgua e nutrientes do solo e diminuindo a velocidade do vento.

En decorrência destas interferências, há uma modificação no microclima que, por sua vez, induz alterações nos processos fisiológicos e nas características da cultura protegida. Os efeitos dos quebraventos estão representados na figura 1 . 


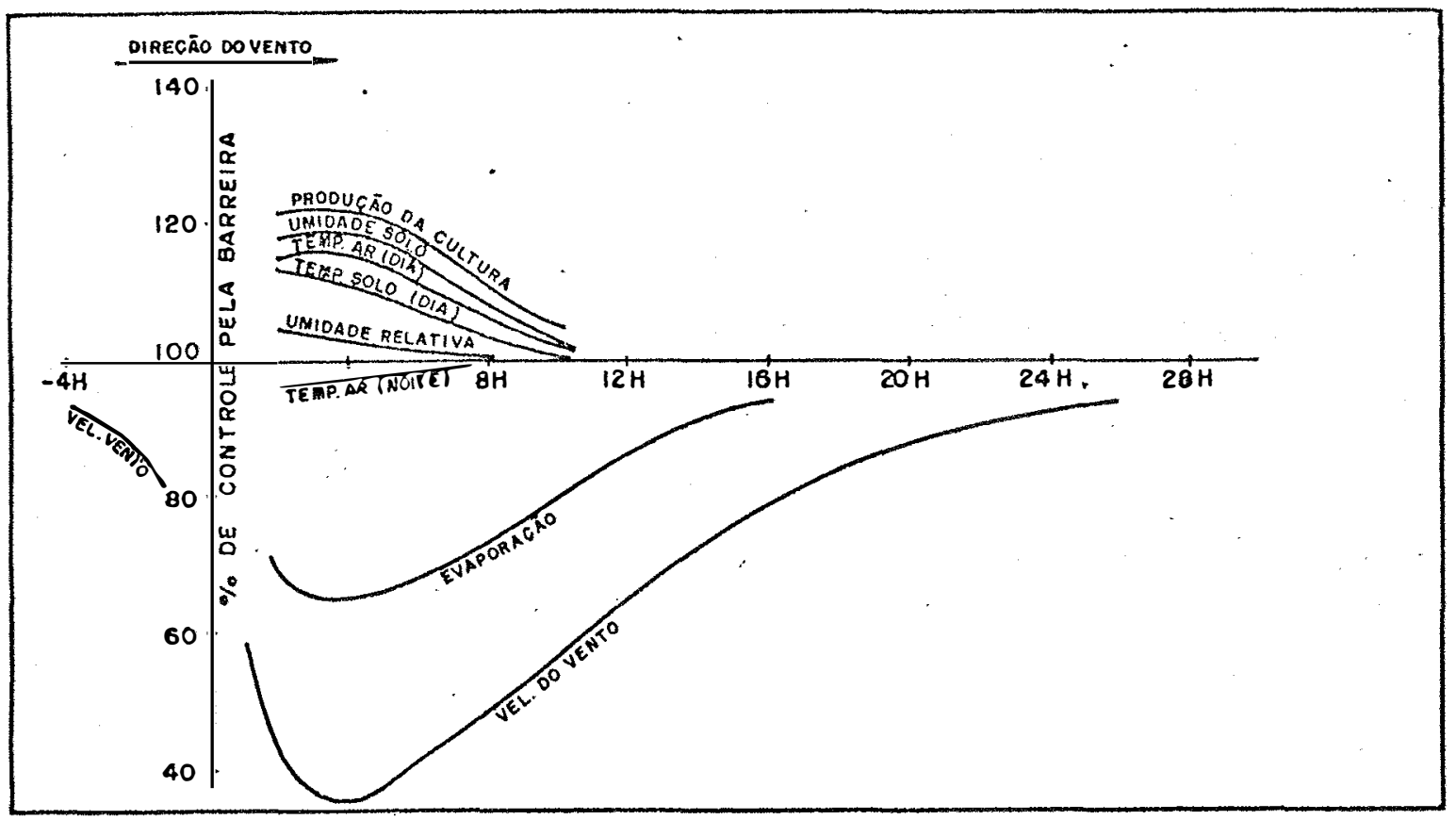

Figura 1. Diagrama sumário dos efeitos dos quebra-ventos sobre fatores microclimáticos e outros (de Marshall, apud SIDDOWAY, 1970).

\subsubsection{Efeitos diretos dos nuebra-ventos}

a) Redução na veløcidade do vento

A distância, en tenos de múltiplos da altura da banceira (H) , sobre a qual um quebra-vento é efetivo na redução da velocidade do vento é um ponto controvertido na pesquisa. Para BATES (1911), essa distância é 10H (dez vezes a altura da barreira). Para TRENK ( 1914 ) e STAPLi e IEHANE (1955), 20H.WEAVER e CIEMEIVTS (1950) observam que o limite do efeito é $20 \mathrm{H}$, mas que este efeito só é considerável de 5 a $10 \mathrm{H}$ e, às vezes, até $15 \mathrm{H}$.

outros autores lembram que hã um efeito notável a sota 
vento ${ }^{(1)}$ e un efeito mais restrito a barlavento (2), sendo que. a efetividade do quebra-vento será deteninada pelo somatório de ambos. A FAO (1956) considera que há efeito até 3H a barlavento e 10H a sotavento ; BROWN e HALL (1968) afirmam que o efeito se estende até 2 a 5H (a barla vento) e 15 a $20 \mathrm{H}$ (a sotavento) e O'ROURKE (1976) refere-se respectivamen te a $5 \mathrm{H}$ e 10 a $30 \mathrm{H}$.

Para avaliar a intensidade da proteção que a barreira oferecé, todos os autores adotam a metodologia proposta por BATES (1911), em que os dados de velocidade do vento na área protegida são colocados em porcentagem da velocidade do vento em campo aberto, tomada simultaneamente. Para CABORN (1962), esta velocidade pode ser tomada a $20 \mathrm{H}$, e o tempo de medição para cada ponto pode ser de 10 ou 15 minutos. SEGUII e GIGNOUX (1974) recomendam 30 minutos.

GUYOT (1963) afinna que en uma série de quebra-ventos paralélos hâ uma redução de $65 \%$ na velocidade do vento até $7,5 \mathrm{H}$ e de $53 \%$ até 15H. Mc CALL et alii (1970) observaram que há uma redução de 70 a $75 \%$ até $3 \mathrm{H}$, de 40 a $50 \%$ até $10 \mathrm{H}$ e de 20 a $30 \%$ até $20 \mathrm{H}$, e sugeren que as barreiras sejam espaçadas de tal maneira que ofereçam redução de $50 \%$ na velocidade do vento. LEYTON (1983) considera como zona protegida toda a área en que a velocidade do ventó é reduzida em pelo menos $20 \%$.

No entanto, "a efetividade de um quebra-vento depende não tanto da porcentagem de redução na velocidade do vento que pode fornecer, mas de quão efetivo é na redução da velocidade abaixo do limite critico requerido para impedir a erosão do solo ou prevenir a inibição do crescimento das plantas" (WOODRUFF et alii, 1959). Partindo deste princípio, Mc CALL et alii (1970) estabeleceram a seguinte relação:

(1) vento procedendo ao quebra-vento.

(2) vento antecedendo ao quebra-vento. 
velocidade do vento efeito

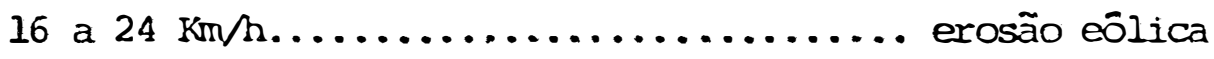

- redução na polinização

- redução na atividade dos insetos

24 a $32 \mathrm{~km} / . . \ldots \ldots \ldots \ldots \ldots \ldots \ldots$ danos mecânico. às plantas.

SEgundo OMEITO e CARAMORI (1981) a velocidade do, vento mais conveniente e ūtil para o estimulo das atividades fisiológicas, na maioria das plantas, está entre 1,4 e $1,6 \mathrm{~m} / \mathrm{s}(5,0$ a 5,8km/h). Este dado coincide can o limite māximo da taxa fotossintética encontrado por DENE$\mathrm{KE}$ (1931), de 1,6m/s (5,8k//h). Pesquisando o nabo (Brassica napus), iADS WORTH (1959) constatou que a velocidade do vento que traz ' crescimento ótimo para esta cultura é de $0,3 \mathrm{~m} / \mathrm{s}(1,08 \mathrm{Km} / \mathrm{h})$.

A suscetibilidade à erosão élica varia de um para outro tipo de solo, sendo que para solos arenosos tem inicio quando o vento, a 1,35m do nível do solo, está a 22,4Km/h (STOECKETER, 1963). Para wOODRUFF et alii (1963), quando a velocidade do vento atinge $22,5 \mathrm{~km} / \mathrm{h}$, tem inicio a erosão eólica.

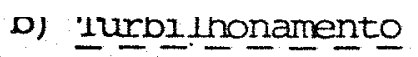

O turbilhonarnento, que é um efeito negativo, pode ocorrer quando a barreira é muito compacta, ou seja, de baixa penneabilidade (IBARRA, s.d.; CAMARCO, 1965/66 e BROW e HALI, 1968).

Quando o quebra-vento é pouco permeável, a maior parte do vento é desviada para o alto. Como o vento que passa através da barreira é pouco, é criada uma força de sucção que provoca o turbilhonamento, fazendo com que a zona de eficácia seja reduzida, embora o grau de proteção seja elevado (GUYOT, 1963).

A solução para evitar este efeito negativo é utilizar barreiras relativamente permeáveis, que agern reduzindo a velocidade do ven- 
to e não bloqueando o seu fluxo.

c) Sombreamento (competição por luz ).

O quebra-vento lança sobre a cultura a sua sombra, e pode se estabelecer uma competição por luz en uma faixa prōxina à barreira.

Para BATES (1911), uma única rua de árvores pode usar $75 \%$ da luz que poderia incidir sobre uma faixa de $15 \mathrm{~m}$ de largura junto às àrvores e $25 \%$ nos próximos $15 \mathrm{~m}$. Camo solução para reduzir as perảas decorrentes deste sombreamento, 0 autor sugere:

- plantar na área scmbreada culturas cujo valor não depen da da produção de grãos;

- usar para quebra-vento espécies que formeçam pouca sanbra;

- locar estradas nas áreas sombreadas.

A orientação do quebra-vento em relação ao sol irá determinar a extensão e a intensidade do sombreamento. BATES (1911) considerava a orientação norte-sul pior, jā que o volume a a área sombreados são maiores. porém, en trabalhos mais recentes, vários autores concordam em afirmar que a melhor orientação é exatamente aquela (norte-sul) (GUYOT, 1963; BROWN e HALI, 1968), pois o sombreamento é temporário e toda a área recebe insolação diariamente por algum terpo. con orienta ção leste-oeste há una perda de área considerável devido ao sombreamento, que é permanente, e especialmente no inverno, quando a área sombrea da è maior.

Segundo Mc CAII et alii (1970), o quebra-vento campete por luz com a cultura até 1,5H. TIGRE (1972) considera o sombreamento problenātico até 45\%, ou seja, 1 H.

Alguns autores relatam casos de diminuição de produtivida de decorrente do sombreamento. Assim, RADKE e BURPOWS (1970) observaram que a soja protegida por quebra-vento de milho não se desenvolve muto ben junto às ruas de milho. Na India, VORA et alii (1982) registraram 
queda de produtividade de $58,1 \%$ para o trigo e $14,9 \%$ para a mostarda cultivados sob as ärvores do quebra-vento. Diante disso os autores recomendarm que não se cultive esta faixa de terra.

d) Absorção de āgua e nutrientes (competição radicular)

A absorção de água e nutrientes pelas ärvores dos quebraventos, estabelecendo com a cultura uma competição radicular, è um problema real e vem sendo pesquisada há muito tempo. Este parece ser o ponto mais polêmico sobre a utilização dos quebra-ventos.

Ainda no século passado, CARD (1897) constatava que "há um efeito injurioso junto ao quebra-vento pela perda de umidade e ferti lidade do solo causada pelas árvores".

BATES (1911) despreza a competição por nutrientes, afirmando que, em termos de fertilidade do solo, o que è retirado pelas àrvores é devolvido pela queda de folhas. Em 1944, o mesmo autor afirma que as raizes dos quebra-ventos retiram umidade e nutrientes do solo adjacente, alën de sombrear a cultura, prejudic ando o seu desenvolvimen to.

Os efeitos da absorção de água e nutrientes pelas árvores da barreira variam também com a espécie cultivada, sendo que a alfafa é uma das culturas menos afetadas, por ter sistema radicular abundante e profundo (BATES, 1944).

GREB e BIACK (1961), estudando os efeitos de um quebravento de Pinus strobus sobre culturas de trigo e sorgo, observaram que ambas as culturas apresentaram deficiência de nitrogênio e falta de unidade em una faixa de $25 \mathrm{~m}$ de largura junto da barreira. Consegllentemente, houve queda na produção e, para o trigo, atraso de 10 dias no amadurecimento.

A faixa em que se estabelece a competição varia com a espécie plantada como quebra-vento, com a cultura e com o clima. Os autores divergem ligeiramente quanto à largura tolerável para esta faixa. Para BATES (1911), esta largura pode estar entre 0,5 e 3H. Para WALKER (1946) até lH e para GURGEI FILHO (1969) até 0,5H. Mc CALl et alii 
(1970) afirmam que há competição até 1,5H, por luz, umidade e nutrientes.

A largura desta faixa corresponde ao limite do alcance das raỉzes do quebra-vento. WIIUIS et alii (1976) afirmam que a maior parte das raizes, tanto dos arbustos como das árvores, concentra-se nos 1,20 m superficiais do solo. Em termos de expansão lateral, têm sido encontra dos casos em que as raízes atingem até o dobro do limite da copa (IEYTON, 1983).

De modo geral, a solução proposta para o problema se resume a:

- escolher, para quebra-vento, espécies que não estendam muito suas raĩzes (que tenham raízes pivotantes) (BATES, 1911);

- plantar junto à barreira culturas que não sejam muito . . suscetíveis à falta de água (BATES ,1911);

- não plantar na faixa junto aos quebra-ventos ( WEAVER e CLEMENTS, 1950);

- locar estradas junto aos quebra-ventos (O'ROURKE, 1976) ;

- impedir a expansão lateral do sisterna radicular das ārvores da barreira.

Dentro desta última recomendação, vārios autores propõen alternativas. BATES (1911) propõe cultivo do solo adjacente, aração profunda anual e até o uso de dinamite antes da implantação dos quebra-ventos para estimular o aprofundamento das raízes. Segundo ANDERSON (1935), não se deve usar "mulching" ou cobertura morta junto aos quebra-ventos novos, pois isto irá estimular o crescimento de raỉzes superficiais e evitar o aprofundamento das raỉzes, aumentando a competição. : Pode-se usar, segundo o autor, apenas areia, barro ou pedra para evitar a perda de unidade. STOECKELER (1963) recomenda a poda de raízes até 60-80am de profundidade, 3 a $6 \mathrm{~m}$ de distância das ärvores. GURGEL FILHO (1969) propõe a subsolagem de uma faixa de $2,5 \mathrm{~m}$ junto ao quebra-vento. TIGRE (1972) sugere a abertura de valetas a 2n de distância das plantas culti 
vadas.

2.4.2. Efeitos indiretos dos quebra-ventos sobre o microclima

o quebra-vento induz uma sererie de modificações no microclima, todas elas decorrentes da redução na velocidade do vento e, às vezes, do sombreamento.

a) Balanço de radiação

ROSENBERG (1976), estudando os efeitos do quebra-vento so bre o microclima, concluiu que não hã alteração significativa no balanço de radiação, exceto junto à bałreira.

b) Temperatura do ar

En 1911, BATES já assinalava que hã um aumento da amplitú de térmica diāria, decorrente da estagnação do ar. Segundo o autor, a armplitude é maior no ponto de maior eficácia do quebra-vento, não sendo notada em dias nubiados, e o pico da curva de temperatura coincide com o pico da curva de produtividade.

De uma forma ou de outra, estas constatações viriam a ser confinnadas e acrescidas de novas observações por outros autores posterionmente. WEAVER e CLEMENTS (1950) quantificam este efeito e lafimam que a amplitude térmica diāria é 9\% maior na ārea protegida.

GUYOT (1963) observa que estes efeitos nem sempre são benëficos, podendo haver agravamento das geadas com a intensificação do . frio à noite e, por outro lado, há uma intensificação do calor durante o dia. Para este autor, as modificações térmicas dependem do clima e, de modo geral, há una elevação da temperatura do ar nos climas úmidos e um abaixamento em climas secos.

ROSENBERG (1966 e 1976) registra o aumento da temperatura diurna e a redução da temperatura noturna na ārea protegida. Mc CALl et alii (1970) verificam un aumento de até 9 a 109F $(5$ a 5,69C) e BROWN 
e ROSENBERG (1972) detectam um aumento de 1,89C na temperatura diurna da ārea protegida.

Na India, em 1982, VORA et alii observaram una diminuição de $3,40 \mathrm{~F}(1,99 \mathrm{C})$ na temperatura do ar.

c) Umidade do ar

o quebra-tento altera a distribuição da umidade do ar. Há um aumento na capacidade de retenção de umidade, decorrente do aumento da temperatura do ar (BATES, 1911).

A pressão de vapor é sempre maior na área protegida (ROSENBERG, 1966; MULLER et alii, 1973). Esse aumento, segundo BROWN e ROSENBERG (1972) è da ordem de 4, ombar.

Devido à redução da velocidade do vento, o tranșporte de vapor é reduzido, a umidade absoluta é mais alta durante todo o tempo e a umidade relativa é superior, mesmo durante o dia, a despeito da elevação da temperatura do ar na área protegida (ROSENBERG, 1976).

VORA et alii (1982) constataram um aumento de 5,8\% na umidade relativa do ar sob a proteção por quebra-ventos na India.

d) Evapotranspiração

Todos os autores consultados que estudaram a evaporação e a evapotranspiração, real e potencial, em áreas protegidas por quebraventos, são unânimes em afirmar que há uma redução nestas taxas em relação ao campo aberto (BATES, 1911; FININEL, 1928; WEAVER e CIENEINTS, 1950; WOODRUFF et alii, 1959; BOUCHE' et alii, 1963; GUYOT, 1963; BROWN e HALL, 1968; MC CALL et alii, 1970; MILIER et alii, 1973; BOTIOMIEY e PARKER, 1974; ORMAN, 1976; ROSENBERG, 1976 e HANSON e RAUZI, 1977). As maneiras a que chegaram à esta conclusão e a intensidade da redução en contrada é que variam de um autor para outro.

WEAVER e CIEMENTS (1950) afimam que, quando o efeito da proteção é máximo, a evaporação pode ser reduzida em até 70\% a uma distância de 1 a 2H, mas con um vento de $24 \mathrm{Km} / \mathrm{h}$ a ređução é de apenas 15 a , 20\%. 
WOODRUFF et alii (1959), em un estudo semelhante, constataram que há redução na evapotranspiração entre 2,2 e 12H, com redução máxima de 21 a 31\% no ponto $2,2 \mathrm{H}$ à noite, no começo da manhã e no fim da tarde, sendo que ao meio-dia a ređução máxima foi de $20 \% \mathrm{em} 8,6 \mathrm{H}$.

Mc CALL et alii (1970) observaram redução em atē 40\% "' na evaporação em áreas protegidas por quebra-ventos no Havaĩ. MILLER et alii (1973) obtiveram redução de 20\% na evapotranspiração real, usando quebra-ventos artificiais.

BOTTOMLEY e PARKER (1974) estabeleceram uma relação importante, que permite estimar a redução na evapotranspiração a partir da re dução na velocidade do vento. Segundo estes autores, com uma redução da velocidade do vento a 25\% a evapotranspiração è reduzida à metade.

HANSON e RAUZI (1977) estudaram a evaporação em tanque classe A e verificaram que a taxa foi $14 \%$ inferior na ārea protegida.

\section{e). Precipitação}

FERBER (1958) afima quie a irrigação por aspersão pode se tormar mais fácil e a superfỉcie mais efetiva na presença de quebra-ventos. O mesmo raciocínio é aplicado por GUYOT (1963), que afirma que quándo a velocidade do vento é baixa, a chuva cai verticalmente, fázendo com que a quantidade de chuva por unidade de área seja maior. No entanto, esta é uma vantagem discutível, jā que fatalmente a área atingida pela chuva serä menor.

Una armpla revisão sobre precipitação e quebra-ventos foi elaborada por GUYOT. (1963). O autor relata que, na URSS, que tem um cli ma tipicamente continental, os quebra-ventos ativam o ciclo interior da āgua, ocasionando um aumento de 1 a 2\% na precipitação, podendo ultrapas sar 5\% na Europa Centràl. A homogeneização da distribuição da neve contribui tambëm para a entrada de água no sistema e, com a diminuição do escoamento superficial, há. uma elevação e melhora na alimentação do lençol freático. O autor ressalta ainda que um outro aspecto importante em relação à entrada de água no sistema è a deposição de orvalho. Em sua revisão, observa que há um aumento na deposição de orvalho, pois a umida 
de relativa é maior e a temperatura noturna é menor na ārea protegida. Steubing, apud GUYOT (1963), menciona um aumento de 200\% na deposição de orvalho. Para ROSENBERG (1976), além do aumento na deposição hā um aumento na duração do orvalho na ärea protegida.

As ārvores dos quebra-ventos interferem ainda reduzindo o escoamento superficial (RADVANYI; 1978) e alterando o padrão de inter ceptação da precipitação (IEYTION, 1983) .

\subsubsection{Efeitos indiretos dos quebra-ventos sobre o solo}

a) Temperatura do solo

A temperatura do solo nu nas áreas protegidas por quebraventos é maior do que nas áreas desprotegidas, o que é mais importante na primavera, segundo GUYOT (1963) .

Para ROSENBERG (1966) a curva de temperatura do solo acom panha a curva de temperatura do ar, sendo mais elevada durante o dia e inferior durante a noite nas äreas protegidas, em relação ao campo aber to.

BOTIOUVILEY e PARKER (1974) correlacionam o aumento da temperatura do solo com um crescimento mais räpido das plantas e RADVANYI (61978) afirma que, na URSS, os quebra-ventos são utilizados para redu zir o congelamento em profundidade.

b) Unidade do solo

De maneira geral, os autores concordam que hā um aumento . da umidade do solo nas áreas protegidas por quebra-ventos (BATES, 1911; GUYOT, 1963; PEITON, 1976; RADVANYI, 1978).

BATPS (1911) ressalta que há um aumento na área como um todo, mas que pode haver perda de umidade até uma distância de 5H a par tir da barreira. 
GUYOT (1963) deduz que, se hã um aumento na entrada de água no sisterna e una redução na evapotranspiração real, automaticamente há um aumento na umidade do solo. Em revisão sobre o assunto, o autor refere-se a aumentos da ordem de 3\% a 1,40m de profundidade e de 3 a $11 \%$ a $40 \mathrm{~cm}$.

O efeito sobre a umidade do solo é variável conforme as condições climăticas. WAH e ADEOYE (1984) observaram que durante a época das chuvas não houve influência, mas logo apös as chuvas a depleção da umidade da superfície do solo foi mais rápida na área desprotegida em uma cultura de painço.

c) Propriedades do solo

Segundo FERBER (1958), o solo que é transportado : , pelo vento chega a ter 10 a 20 vezes mais humus e fosfato do que o solo que fica, por ser este mais pesado. Assim, na medida em que reduzem o transporte deste solo, os quebra-ventos estão evitando a perda de fertilidade. Zaev, apud GUYOT (1963), constata que a 5m da barreira os niveis de $\mathrm{P}_{2} \mathrm{O}_{5}, \mathrm{NO}_{3}$ e humus são inferiores ao campo aberto, mas que a $70 \mathrm{~m}$ são duas a três vezes superiores e o pH é mais elevado.

Em relação ao aproveitamento da adubação, Suchoivanov, apud GUYOT(1963), afirma que a eficácia do esterco aumenta em 25\% na ärea protegida, em pastagens.

GUYOT (1963) afirma que os quebra-ventos podem reduzir a salinidade dos solos em regiões costeiras. Para este autor, hä uma melho ra geral nas propriedades físicas e quỉnicas do solo.

d) Erosão_o eólicica

Com ventos de cerca de $22 \mathrm{~km} / \mathrm{h}$ tem início o processo de ero são eólica (STOECKELER, 1963; WOODRUFF et alii, 1963). Na medida em que são capazes de manter a velocidade do vento abaixo deste limite, os quebra-ventos estão impedindo o transporte de solo pelo vento.

o efeito dos quebra-ventos no controle da erosão eólica é 
de tamanha importância que, en 1976, nos EUA, foi realizado um simpósio, denominado "Shelterbelts on the Great Plains", onde foi discutida a utilização de barreiras arbóreas principalmente com esta finalidade; con ter o transporte do solo pelo vento.

GOLDSMITH (1976), neste simpósio, relata os fatores que contribuem para a erosão eólica:

- ausência de umidade;

- crescimento inadequado das plantas e pequeno acúmulo de resíduos;

- "má estrutura do solo;

- terra nua na época do preparo do solo e operações de plantio inadequadas; e

- pástoreio excessivo.

De alguma forma os quebra-ventos podem amenizar todos estes fatores e, consequentemente, conter a erosão eólica.

LYLES (1976), buscando quantificar o efeito dos quebraventos sobre a erosão eólica verificou que a variação no potencial de erosão eólica ("wind power"). é proporcional ao cubo da variação na velocidade do vento. Esta relação foi encontrada também por HAGEN (1976), que afinma ainda que a porosidade ideal de una barreira para controle da erosão é de $40 \%$.

\subsubsection{Efeitos indiretos dos quebra-ventos sobre a cultura}

a) Teor de $\mathrm{CO}_{2}$ e fotossintese

GUYOT (1963) afirma que há estagnação do ar com o uso de quebra-ventos, provocạdo um acưrmulo de $\mathrm{CO}_{2}$. Este acúmulo, associado. ao aumento da umidade e da temperatura, faz com que os estônatos permaneçam akertos por mais termpo, intensificando a fotossintese e, conseqlente mente, aumentando também o consumo de $\mathrm{CO}_{2}$ pela cultura. 
Segundo BROWN e ROSENBERG (1972), a variação na concentração de $\mathrm{CO}_{2}$ é de lppm (a menos) durante o dia e 3,5ppm (a mais) durante a noite na ârea protegida.

O aumento da taxa de fotossintese nas culturas protegidas

por quebra-ventos é confimado por MULLER et alii (1973),

BOTICMIEY

e PARKER (1974) e ROSENBERG (1976).

b) Produção de matēria seca e massa foliar

Pesquisando em condições de laboratório, com plantas envasadas e velocidade do vento controlada e constante de $24 \mathrm{~km} / \mathrm{h}$, FINNEL (1928) constatou ura redução de $48,8 \%$ na produção de matéria seca em Calendula.

RADKE (1976), estudando a soja, verificou que, sob a proteção de quebra-ventos a cultura apresentou maior cresçimento, maior produção de matéría seca (30\%) e maior indice de ārea foliar (de 3,8 para 4,4$)$.

Para o trigo de inverno, SKIDMORE (1976) observou que houve aumento no crescimento e na produção de matéria seca.

CANNEL (1983) confirma as observações anteriores, verifi cando maior crescimento en altura, aumento na produção de matéría seca e na frutificação da cultura protegida, principalmente devido, segundo o autor, à melhoria das condiçōes hỉdricas.

c) Polinizização

Diante da redução na velocidade do vento, há uma intensificação na atividade dos insetos polinizadores e, consequlentemente, a polinização é facilitada. Este fato foi observado em pomares de maçãs por CARD (1897) e em girassol por GOMES (1972) .

d) Proteção contra danos provocados pelo vento

Com a redução na velocidade do vento, os danos mecânicos 
e fisiológicos dele decorrentes são reduzidos.

FINNEL (1928) observou que um vento constante de $24 \mathrm{krm} / \mathrm{h}$ causou os seguintes danos em plantas envasadas:

- destruição parcial da follhagem;

- defonnação do fuste;

- redução na taxa de crescimento; e

- atraso na maturação.

o quebra-vento pode reduzir sensivelmente as quebras de produção causadas pelo acamamento da cultura quando há ventos fortes. Es te efeito é citado por BATES (1944) e FERBER (1958).

Segundo o IBC (1981), os quebra-ventos reduzem os danos me. cânicos causados pelo vento à cultura do café, como:

- ferimentos e dilaceração da folhagem;

- quebra de flores e frutos;

- crestamento pelo vento frio;

- abalo das madas; e.

- canela de vento.

e) Prag gas_e doenças

Sob este aspecto os quebra-ventos podem beneficiar ou, âs vezes, prejudicar a cultura.

Para GUYOT (1963), as árvores da barreira podem servir de abrigo para espécies animais e vegetais estranhas à cultura, que podem ser inimigos naturais das pragas, ou inimigos da própria cultura.

MC CALL et alii (1970) observam que, embora possam ser benéficos por abrigar a fauna silvestre útil ao controle biológico de pragas, os quebra-ventos podem provocar aumento na incidência de certos tipos de doenças, pela elevação da temperatura e da unidade.

Sobre o café, especificamente, VIANA et alii (1978) afirmam que os quebra-ventos exercen una ação benéfica, pois os ferimentos provocados pelo vento nos cafeeiros jovens dão acesso a agentes patogêni 
cos (fungos e bactérias), provocando a "seca de ponteiros" . O IBC (1981), para a mesma cultura, menciona a redução na incidência de doenças decorrentes do vento, como a "mancha aureolada".

\subsection{Usos dos quebra-ventos.}

A finalidade com que os quebra-ventos são implantados e mantidos em una certa região é miito variável e está relacionada principalmente com o clima e, às vezes, com as atividades econônicas desta região.

A proteção de culturas alimentîcias visando o aumento de produtividade é a utilização mais comum dos quebra-ventos. O efeito atra vés do qual se espera este aumento de produtividade é que é muito variável.

2.5.1. Proteção contra a erosão ëōlica

E utilização mais comm dos quebra-ventos nos EUA (TRENK, 1914; BATES, 1944; FERBER, 1958; STOECKELER, 1963; EATOIN, 1971; AASE et alii, 1976; GOIDSMTIH, 1976; e GRIFFITH, 1976). A erosão eólica é um problema sério nos EUA, especialmente nas grandes planícies. BATES (1944) relata que en Oklahoma o vento chega a arrancar duas ou três vezes as plântulas de algodão nos solos arenosos.

Também são utilizadas barreiras arböreas com esta finalidade no Canadá (WALKER, 1946), na Itália (GURGEL FILHO, 1969), en Angola (GOMES, 1972), na Austrália (ORMAN, 1976), na URSS (RADVANII, 1978), na Bulgária (DZHODZHOV e GEORGIEV, 1980).

\subsubsection{Redução da evapotranspiração}

E o uso mais comum dos quebra-ventos nas regiōes de clima seco, como as estepes soviéticas, onde as culturas sofren pelo frio e pe la falta de umidade (RADVANYI, 1978).

Com esta finalidade os quebra-ventos são empregados ainda 
nos EUA (BATES, 1944 e STOECKELER, 1963), no Canadâ (WALKER, 1946), em Angola (GOMES, 1972), na Austrália para proteger dos ventos quentes e se cos no verão (ORMAN, 1976), na Bulgăria (DIMITROV e KUKUIAROV, 1977), e nas savanas da Nigéria (UJAH e ADEOYE, 1984).

\subsubsection{Proteção contra doenças e danos mecânicos}

A proteção contra danos mecânicos, como o acamamento, geralmente está associada a outras finalidades. E mencionada por BATES (1911 e 1944), WALKER (1946) e FERBER (1958).

VIANA et alii (1978) referem-se à utilização de quebraventos para proteger o café dos danos provocados pelo vento e das doenças deles decorrentes. Esta parece ser a principal finalidade da instala ção de quebra-ventos nas lavouras de café no Brasil.

\subsubsection{Retenção e distribuição da neve}

Nos países onde a neve é comum e abundante no inverno, os quebra-ventos podem melhorar a sua distribuição, beneficiando as culturas e evitando os danos que podem ocorrer quando do derretimento desta neve. Com esta finalídade as barreiras arbóreas são utilizadas no Canadá (BATES, 1944), nOs EUA (BATES, 1944, ; FERBER, 1958; EATON, 1971, AASE et alii, 1976) e na URSS ( RADVANYI, 1978).

\subsubsection{Protecão das pastagens e do gado}

WALKER (1946) coloca entre os usos mais comuns de quebraventos no Canadá a proteção ao gado.

Segundo FERBER (1958), as vacas leiteiras produzem mais é consomem menos alimento quando protegidas do vento.

Na Austrália, a proteção ao gado é mencionada por BROWN e HALU (1968) e em Angola por GOMES (1972). Nos EUA, DAVIS (1976) afima que o gado protegido tem ganhado mais peso em ondições climáticas normais e perdido menos quando o clima è severo. 


\subsubsection{Outros Usos}

Associados aos anteriores, são mencionados com menor frequência outros usos para as barreiras arböreas, como:

a) contenção de dunas e.ventos salinos - principalmente na Europa, e também nos EUA e na URSS, muitas vezes este é o objetivo principal dos quebra-ventos. Este uso é mencionado por BATES (1911 e 1944), GURGEL FILHO (1969) e RADVANYI (1978) .

b) Proteção de edifícios, especialmente na zona rural - para esta finalidade BATES (1944) recomenda que os quebra-ventos sejam colocados a una distância de 2 a 3H, que è a que fornece a melhor proteção. FERBER (1958) afirma que chega a haver uma redução no consumo de lenha da ordem de $15 \%$ ou mais no invemo, além da redução na deposição de poeira.

c) Paisagismo - raramente os quebra-ventos são plantados exclusivamente com fins paisagísticos. No entanto, vários autores se referem a este benefício fornecido pelas barreiras arböreas (BATES, 1911; MC CALL et alii, 1970; ORMAN, 1976; GOIDSMITH, 1976 e VAN DEUSEN, 1978).

d) Abrigo para a fauna - com finalidade de incentivar o controle biológico de pragas. Esta è uma utilização secundária, sempre associada a alguma outra.

e) Produção de lenha e mourões.

f) Apicultura.

\subsection{Economicidade}

A grande indagação a respeito da utilização de quebraventos continua sendo.a seguinte: "os quebra-ventos são economicamente . vantajosos?"

A resposta para esta questão tem que ser simples e se resume a estabelecer se os ganhos de produtividade superam as perdas decorrentes da competição e da perda de área.

Para BATES (1911), embora possam ser usados para melhoria 
da qualidade ambiental, os quebra-ventos só devem ser recomendados quando o valor da madeira e da proteção forem iguais ou superiores ao va lor da cultura que poderia estar sendo feita em seu lugar. Os ganhos e perdas estão representados esquematicamente na figura 2.

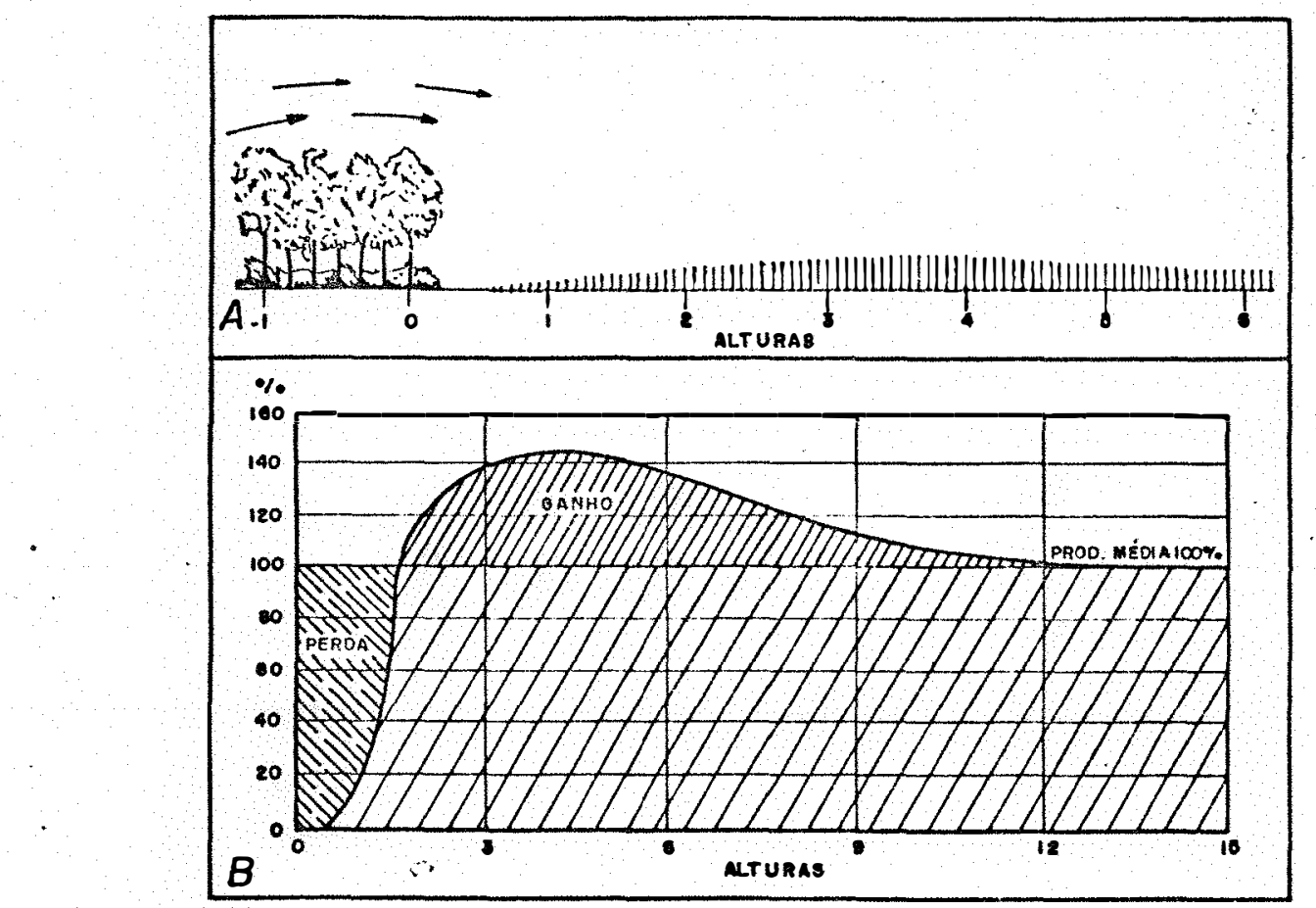

Figura 2 - Ganhos e perdas decorrentes do quebra-vento, em relação à produção média em campo aberto (de BATES, 1944).

Na verdade, a melhoria da qualidade ambiental raramente é lembrada pelo agricultor. o que conta, realmente, è o balanço econômico, o que ele ganha ou deixa de ganhar en capital no final da safra.

CAMARGO (1965/66) considera que, para que compense utili zar quebra-ventos, o aumento de produção decorrente da proteção deve ser maior que a perda decorrente da perda de área.

De modo geral os autores concordam que, na maioria dos casos, os benefícios fornecidos pelas barreiras podem superar a perda de espaço e o custo do investimento (FERBER, 1958 e BOTOMLEY e PARKER 1974). 
FERREIRA et alii (1976) consideram que com uma ocupação de até 10\% da área pelos quebra-ventos, pode haver um aumento de 10 a 15\% na produção, além de reduzir os custos da cultura.

\subsection{Casos àe aumentó de produtividade}

O quebra-vento exerce efeitos negativos sobre a cultura na quela faixa onde se estabelece a competição com a espécie cultivada. Aí ocorre uma queda de produtividade que tem sido mencionada para justifi car a eliminação dos quebra-ventos en algumas propriedades ( "FERBER, 1958; GOLDSMITH, 1976; DAVIS, 1976 e VAIN DEUSEN, 1978) .

A eliminação tem sido explicada ainda por outros motivos, baseados sempre no prejuízo à produtividade da ārea plantada, como por exemplo:

-- ocupação de espaço (FERBER, 1958; DAVIS, 1976 e GOLDSMITH, 1976;

- atraso do plantio pelo acúmulo de neve (FERBER, 1958);

- empecilho à irrigação com pivô central (DAVIS, 1976; GOLDSMITH, 1976 e VAN DEUSEN, 1978) •

No entanto, tudo indica que os efeitos benéficos superam as perdas, tomando compensador o uso de quebra-ventos. São inümeros os casos de aumento de produtividade encontrados na literatura e alguns estão relacionados a seguir:

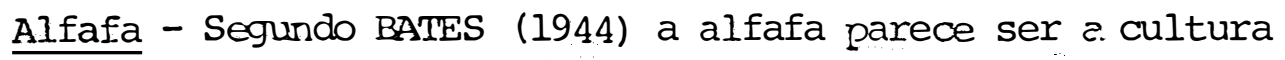
que melhor responde aos quebra-ventos, chegando a apresentar até 60 a $70 \%$ de aumento na produção, quando protegida do vento.

Café - Ėmbora não tenha sido localizado nenhum trabalho. de pesquisa, sobre a produtividade do café com o uso do quebra-ventos, $\underline{\text { A }}$ MARGO (1965/66) estima que as perdas decorrentes do vento nas faces mais expostas chegam a atingir $30 \%$

Feijão - ROSENBERG (1966) menciona aumento de 5,9\% na produção de feijão irrigado, quando protegido por quebra-ventos. 
Girassol - TKATCHENKO (1950) obteve uma produção de girassol 18\% maior em áreas protegidas do vento na Rússia meridional.

Iaranja - E comm o uso de barreiras arbóreas para proteção de pomares, mas há poucos dados referentes a aurnento de produtividade de frutíferas. Para'a laranja, na Califömia, WEAVER e CLEMENTS (1950) afirmam que há um aumento de $24 \%$ na produção com a proteção contra o ven to.

Milho - Muitas vezes o milho é utilizado como quebra-vento para culturas de menor porte, mas, às vezes, o milho é a cultura prote gida. BATES (1911) relata que, com um vento de $80 \mathrm{Km} / \mathrm{h}$, houve uma perda de $2 / 3$ do milho por acamamento em áreas desprotegidas, enquanto que nas áreas protegidas não houve nenhuma perda até $6 \mathrm{H}, 10 \%$ de perda de 6 a $8 \mathrm{H}$ e 25\% de 8 a 12H. O mesmo autor, em 1944, observou um aumento de produção para o milho de 1800 litros/ha em anos de seca e calor. Caluianu et alij apud GUYOT (1963) obtiveram 14 a 34\% a mais na produção de milho na Romênia e, na Bulgária, DIMITROV e KUKULAPOV (1977) registraram 8 a $9 \%$ de aumento em una faixa de $250 \mathrm{~m}$ com quebra-ventos.jovens (de pequena altura) e 9 a 34\% com quebra-ventos antigos (altos).

Pastagem - Segundo GUYOT (1963), é freqlente as pastagens protegidas do vento produzirem $100 \%$ a mais que as não protegidas, nas estepes secas do sul da Rússia.

Soja - Analisando a produtividade da soja protegida por quebra-ventos de milho, RADKE e BURROWS (1970) verificaram um aumento de $12,7 \%$ e RADKE (1976) obteve 10\% de aumento. Com barreiras artificiais, FRAivK et alii (1974) obtiveram 8,5\% a mais na produção de soja não irrigada e $17,6 \%$ para a soja irrigada.

Trigo - Trata-se, sem dúvida, da cultura que mais tem sido beneficiada pelos quebra-ventos através do mundo. WEAVER e CLEMENTS (1950) afimam que, na Rússia, em anos de seca, o trigo da estepe produziu de 135 a $540 \mathrm{Kg}$ a mais por hectare. TRATCHENKO (1950) verificou aumentos de $41 \%$ para $\circ$ trigo de invemo e $21 \%$ para $\circ$ trigo de primavera, na Rússia meridional. No Canadá, STAPLE e LEHHANE (1955) encontraram uma pro 
dução 3,3\% superior, considerando toda a área utilizada. GUYOT (1963)... menciona $11,1 \%$ a mais na produção de grãos e $12,6 \%$ a mais de palha de trigo, na Dinamarca, 23\% a mais de grãos na Romênia e, em outro caso na Romênia, 20 a 50\%. Na Bulgária, DIMITROV e KUKULAROV (1977) obtiveram, para uma faixa de $250 \mathrm{~m}$ de largura a partir do quebra-vento, aumentos de 6 a 7\% quando as árvores da barreira eram jovens (baixas) e 18 a 21\% com árvores mais antigas (altas). VORA et alii (1982) verificaram, na India, uma produção 22,7\% superior para o trigo protegido do vento.

Outras culturas - Constataram-se casos de aumento de produção em muitas outras culturas, tais como: algodão, aveia, batata, beterraba, centeio, cevada, mostarda, nabo, painço e tremoço.

\subsection{Estrutura dos ruebra-ventos.}

Un quebra-vento será mais ou menos eficiente dependendo do clima do local e das características da barreira. Se, por um lado, - clima não se pode mudar, por outro, a estrutura pode ser planejada de forma a proporcionar a melhor proteção possível para o elemento que se quer proteger. No processo de planejamento de um quebra-vento, cada i.tem determinante da estrutura da barreira deve ser analisado individual mente, para que se possa obter a proteção máxima.

\subsubsection{Altura}

A altura é a característica mais importante a considerar, pois irá determinar a extensão da área protegida. Praticamente todos os autores consultados utilizam o valor da altura das árvores adultas (H) como unidade de medida de distância em relação à barreira. Isto por. que o efeito do quebra-vento está diretamente relacionado com este parâa metro. Se un quebra-vento é efetivo por uma distância de $10 \mathrm{H}$, e ele tem $10 \mathrm{~m}$ de altura, a faixa protegida será de $100 \mathrm{~m}$. Se o mesmo quebra-vento tivesse $15 \mathrm{~m}$ de altura, essa faixa seria de 150m, ou seja, 50\% a mais de proteção para una mesma ocupação de espaço. 
E perfeitamente cortireensivivel, portanto, a recomendação de GOMES (1972), dentre outros, de que a altura deve ser a máxima possível. Um outro aspecto importante em relação à altura è a homogeneidade, pois assim a faixa protegida e o grau de proteção serão tambëm homogêneos (SEREDINA e KARPACHEVSKII, 1982 e WOODRUFF e ZINGG, 1953).

A melhor maneira de se conseguir uma barreira de altura homogênea e eficiente é através da escolha da espécie e do material gené tico.

\subsubsection{Peneabilidade}

Permeabilidade, porosidade ou densidade são parâmetros uti lizados para avaliar um único aspecto relativo à estrutura da barreira : a capacidade de conter o vento. Para a FAO (1956), a eficiência de um quebra-vento depende de vários fatores, mas principalmente deste.

Embora os pesquisadores de modo geral se refirami a este pa râmetro, e até o quantifiquem muitas vezes, são raros aqueles que formecem una metodologia para detenniná-io.

BATES (1944) definia a densidade como porcentagem de redução na velocidade do vento. No entanto, não há como fixar este parâmetro, pois dizer que uma barreira fornece uma redução de 50\% na veløcidade do vento não significa nada. Não se pode saber a que distância foi obtido este valor ou qual a faixa que recebe esta proteção.

Buscando padronizar as medidas para poder compará-las e reconhecê-las, värios autores chegaram a uma mesma definição e a permeabilidade de uma barreira ao vento, ou porosidade, passou a ser a porcen tagem de espaços vazios que esta barreira apresenta (RADKE e BURRowS , 1970; BROWIN e ROSENBERG, 1972; GOMES, 1972 e SKIDMORE, 1976).

Para determinä-la, RADKE e BURROWS (1970) fotografaram i quebra-vento de um ângulo de 90 e projetaram a imagem sobre uma grade quadriculada, para facilitar a quantificação dos espaços em branco.BROWN e ROSENBERG (1972) modificaram ligeiramente a técnica, cortando e pesan do o papel, para evitar cálculos.

A porosidade ideal não é sempre a mesma e deve ser diferen 
te se o que se quer proteger é, por exemplo, uma horta ou una pastagem. De un modo geral, os quebra-ventos têm evoluído de muito densos, imperme áveis, para mais espaçados, permeāveis (SIDDOWAY, 1970) .

GOMES (1972), em busca da porosidade ideal em temos de área protegida, encontrou 35 a 40\% de porosidade, dado este obtido. em túnel aerodinâmico com anteparos.

Hoje, sabe-se que uma barreira muito densa proporciona maior proteção para uma menor distância e que uma barreira pouco densa pro porciona menor proteção para uma maior distância (SKIDMORE, 1976 e REDDY, 1979). Além disso, há o problema da turbulência provocada por que bra-ventos muito compactos, que pode anular o efeito da proteção junto à barreira.

Segundo BOTIOMLEY E PARKER (1974), os quebra-ventos para pastagem devem ser densos na base e permeáveis (50\%) no restante da altú ra e, para agricultura, a permeabilidade deve ser média e homogênea em toda a altura. Para controle da erosão, HAGEN (1976) recomenda 40\% de permeabilidade.

Alēn de recomendar que os quebra-ventos não sejam muito

compactos, os autores são unânimes em afirmar que a barreira não deve apresentar falhas ou "buracos", e deve reter os ramos até o chão, pois o vento se afunila pelas falhas e passa por elas com velocidade aunentada (BATES, 1944; FERBER, 1958; GUYOT, 1963; EATON, 1971; GOMES, 1972 e BOIIOMLEY e PARKER, 1974). Para café, no Brasil, o IBC (1981) afirma que o quebra-vento ideal deve ser moderadamente permeável (50\%), fome cendo uma recução de 50\% na velocidade do vento por una faixa de 10 a $15 \mathrm{H}, \mathrm{e}$, contrariando a regra, recomenda que a barreira seja aberta na base (desrama até 2m) para evitar acúmulo de ar frio em noites de geada, no caso específico desta cultura.

\subsubsection{Orientação}

Sern dưvida, a orientação que formece a melhor proteção é aquela em que a barreira é disposta perpendicularmente ao vento dominante ( WAL KER, 1946; GOITIA, 1956; BROWN e HAIL, 1968; GOMES, 1972 e IBC, 1981). 
A direção do verito dominante pode ser determinada facilmente, segundo DAVIS (1976), pela simples observação das ärvores, ou mesmo a partir da vegetação herbácea (BRAUN-BLANQUET, 1950) .

E importante lembrar que nem sempre o vento dominante e o vento mais severo tên a mesma direção e, neste caso, faz-se necessārio proteger ambas as faces (FERBER, 1958; ORMAN, 1976 e RADVANYI, 1978).

Alguns autores recomendam que o quebra-vento seja projetado de forma a desviar o vento e não rechuzir a sua velocidade e, portanto, de ve estar colocado obliquamente ao vento (EATON, 1971), com um ângulo de 45: do eixo do vento (SEGUIN e GIGNOUX, 1974).

Há uma certa vantagem em dispor os quejra-ventos em recie. RADVANYI (1978) afirma que uma barreira isolada protege até 10 a 12H, enquanto que dispostas em rede podem proteger até $30 \mathrm{H}$.

\subsubsection{Forma do perfil e número de linhas}

Enquanto no ocidente os autores afirmam que o quebra-vento teoricamente ideal tem uma única rua, deve ser ereto e com linha de topo flexivel (WOODRUFF e ZIIJG r, 1953; BÖITOMLEY e PARKER, 1974; VIAiNA et alii, 1978 e IBC, 1981), "os russos insistem sobre a preferência que eles dão aos quebra-ventos complexos, compostos de diversas faixas de árvores e arbustos de diferentes alturas e permitindo uma certa penneabilidade que deve variar em função do clima, do solo, do declive, da força e regularidade dos ventos, levando em conta o problema do turbilhonamento"*

$\mathrm{Na}$ verdade, originalmente a tendência, em todo o mundo, era de usar barreiras multilineares, visando a exploração da madeira. 0 perfil recomendado era aerodinâmico, como o semi-círculo proposto por . BATES (1944) ou a secção triangular proposta por woODRUFF e ZINGG (1953).

Lentamente, os quebra-ventos unilineares foram substituincio os outros. Esta mudança, nos EUA, ocorreu devido ao alto valor da terra, aumento dos intoostos, melhoria nas práticas culturais e nas variedades cultivadas, irrigação e diminuição do uso de ārvores corno lenlıa nas fazendas (HAVERBEKE, 1977).

* Jean Radvanyi, informação pessoal. 
Os russos se viram obrigados a manter a estrutura tradicional, de quebra-ventos multilineares, por causa das severas condições climáticas, en que una barreira unilinear dificilmente conteria a força do vento.

Para a maioria dos autores, a largura ou número de linhas é importante na medida en que afeta a permeabilidade (GUYOT, 1963). Assim, um quebra-vento unilinear, desde que retenha os ramos inferiores e seja unifonmemente permeável, fode ter menor número de árvores, ocupar menor área e exercer muitas das funções esperadas de um quebra-vento multilinear (WOODRUFF et alii, 1963).

Quanto à forma do perfil, as formas retangulares, que começarm e terminam com linhas abruptas, são melhores que aquelas inclinadas para o lado do vento (GUYOT, 1963). Portanto, os arbustos, se necessário, devern ser plantados entre as linhas de árvores (REDDY, 1979).

Embora o perfil deva ser vertical, vários autores recomendarn que a linha de topo deve ser flexível, para não provocar turbilhonamento (BOTTOMLEY e PARKER, 1974; VIANA et alii, 1978 e IBC, 1981).

\section{8,5. Extensão}

O quebra-vento funciona como se fosse uma barragem. As sim, corno se fosse água, o vento tem a velocidade aumentada nas extremidades da barreira, convergindo depois de passar por ela e fazen do com que a ârea protegida seja triangular se o quebra-vento for miito curto (BATES, 1944; BROWN e HALL, 1968; BOTIOMIEI e PARKER, 1974). As figuras 3 e 4 ilustram bern os aspectos relativos à exten são da barreira. 


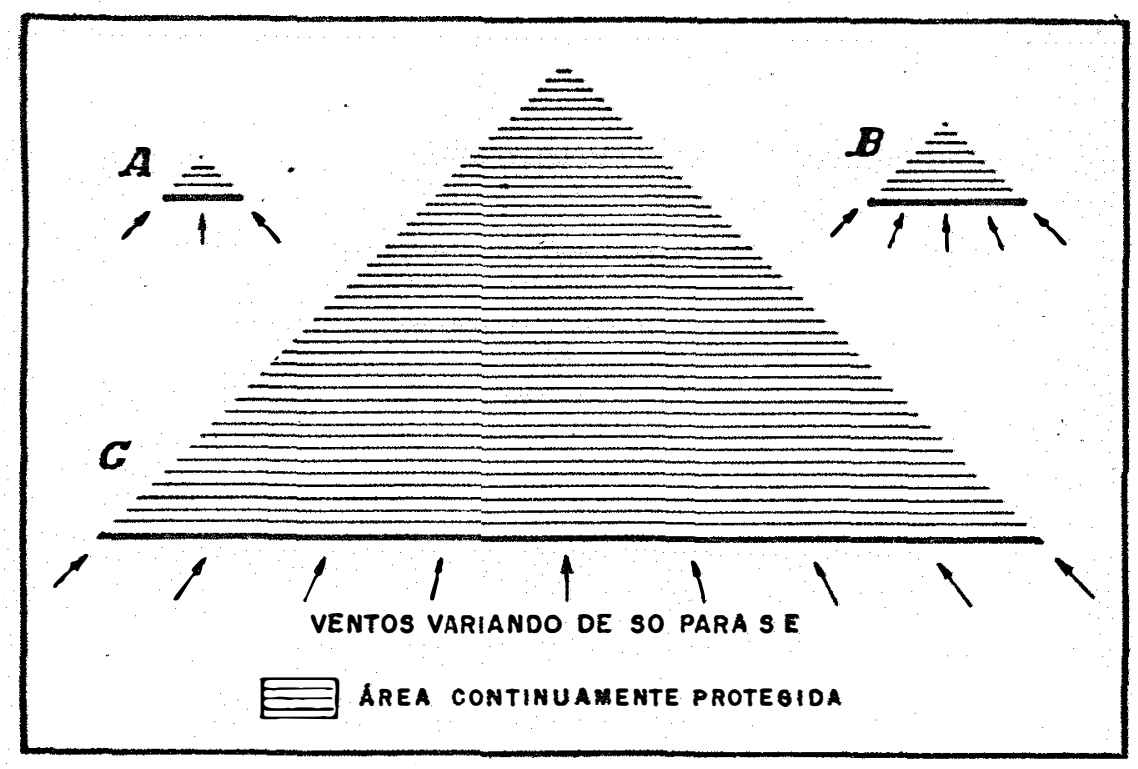

Figura 3 - Area continuamente protegida en quebra-ventos de diferentes extensões (de BATES, 1944).

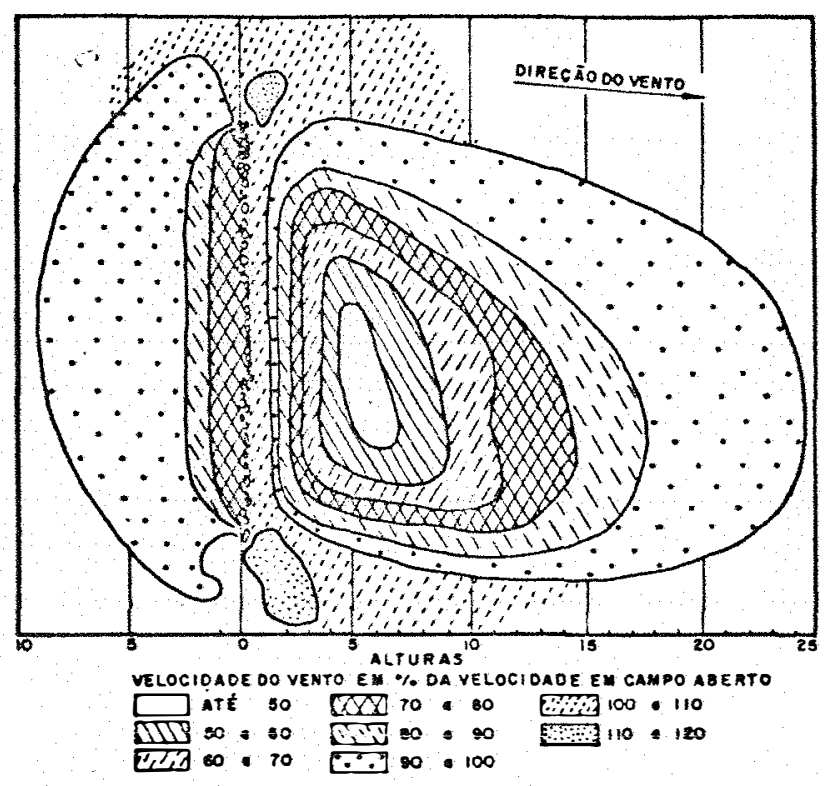

Figura 4 - Area protegida e grau de proteção fomecidos por um quebravento de 19H de extensão, aberto na base (de BATES, 1944). 


\subsubsection{Distância entre linhas.}

A distância entre linhas, ou seja, entre dois quebraventos consecutivos, está. relacionada con o grau de proteção que se dese ja para a cultura e com a altura das ärvores que compöen a barreira. Para padronizar as medidas, convencionou-se determiná-la em múltiplos de H (altura da barreira) .

Para a FAO (1956) essa distância não deve ser maior que $10 \mathrm{H}$.

GOITIA (1956) estabelece diferentes distâncias, de acordo com a velocidade do vento:

- vento de até $3 \mathrm{~m} / \mathrm{s}(10,8 \mathrm{Km} / \mathrm{h}) \quad-\mathrm{D}=\mathrm{H} \times 20+3$

- vento de 3 a $6 \mathrm{~m} / \mathrm{s}(10,8$ a $21,6 \mathrm{Km} / \mathrm{h})-\mathrm{D}=\mathrm{H} \times 30+3$

- vento acima de $6 \mathrm{~m} / \mathrm{s}(21,6 \mathrm{Km} / \mathrm{h})$ - $\mathrm{D}=\mathrm{H} \times 40+3$

sendo D a distância entre as barreiras e $\mathrm{H}$ a altura das árvores.

Lembrando que não se deve proteger apenas un ângulo, BOTTOM LEY e PARKER (1974) recomendam que a distância entre as barreiras perpendiculares ao vento seja de 25 a $30 \mathrm{H}$ e entre as barreiras paralelas de 50 a $60 \mathrm{H}$.

Para RADVANYI (1978), as faixas paralelas ao vento podem distar entre si até 1000 a 2000m.

- IBC (1981) recomenda, para Grevillea robusta em lavoura de café, no Brasil, que a distância entre barreiras consecutivas este ja entre 10 a $15 \mathrm{H}$.

\subsection{Tipos de muebra-ventos.}

Vărios autores tentaram classificar as barreiras arböreas; mas não conseguiram estabelecer um critério fixo.

GUYOT (1963) os separa on vivos e inertes (artificiais) • Mc CALl et alii (1970) classificam os quebra-ventos de três maneiras: Temporários X Permanentes, Plantados X Construídos e Densos X Permeáveis. 
Quanto ao uso, GOLDSMITH (1976) os separa en "field windbreaks", que são os quebra-ventos destinados a reduzir a erosão eólica em āreas agrícolas e "farmstead/feedlot windbreaks", usados para proteger as edificações rurais e o gado.

No Brasil, O IBC (1981) separa os quebra-ventos en quatro tipos, conforme a sua longevidade: arböreos, pernanentes arbusti vos, terporários e anuais.

\subsection{Espécies}

A espëcie ideal para quebra-vento, segundo GUYOT (1963)., deveria reunir as seguintes características:

- ser perenifólia;

- fechar rapidamente;

- possuirisistema radicular tal que a compétição seja limitada; e

-- fornecer um recobrimento reduzido do terreno.

Para CAMARCO (1965/66) as árvores do quebra-vento devem ser esguias, flexiveis, resistentes às quebras e perenifólias.

Para proteger lavouras de café, no Brasil, o IBC (1981) procura espécies permeāveis, eretas, flexíveis, perenifólias, bastante resistentes ao vento, pouco sujeitas a pragas e doenças, que não necessitem condução especial e cujos frutos não se confundam com os do café.

A escollha da melhor espécie é o primeiro passo para que a implantação de um quebra-vento seja bèm sucedida. Para ORMAN (1976) ,nes ta etapa deve-se levar em conta os seguintes fatores:

- clima - pluviosidade e ocorrência de geadas;

- solo - aspecto e drenagem; e

- características da árvore - altura, densidade, formato da copa, caducifolia, toxiciclade da folhagem, absorção radicular e suscetililidade a uoenças.

O ideal seria encontrar a espécie com todas as caracterís ticas desejadas, adạptada às condições de clima e solo do local. com 
este objetivo, muitos autores têm lembrado a necessidade de buscar as melhores espécies e procedências e desenvolver programas de melhoramento genético de árvores para quebra-vento (DAVIS, 1976; STURRock , 1977 e REDDY, 1979).

Na URSS, OZOIIN e TOROKHTUN (1978) referem-se ao uso de plantas de progênies de longevidade comprovada de ulmus pumila var. arborea, e de alguns híbridos com vigor heterótico, pois lá o grande problema é o crescimento e a sobrevivência das árvores nas condições clinná ticas severas a que são submetidas.

Nos EUA já existe uma espécie (Fraxinus pennsylvanica) se lecionada para quebra-vento (CAPSAiv, a break..., 1980).

Inúmeras espëcies têm sido recomendadas por diversos auto res, para diferentes situações. As mais freqlientemente recomendadas, em ordem decrescente de núnero de citações, são as seguintes:

Binus spp - solos arenosos

Eucalvptus spp - regiões tropicais, zonas āridas (E. camaldulensis)

Cupressus spp - formam barreiras impemeäveis.

Grevillea robusta - freqüentemente associada a lavouras de café.

Ulmus spp - para solos secos.

Casuarina spp - zonas costeiras.

Fraxynus spp

Zea mays (milho) - quebra-vento temporário.

Thuja spp - impermeável.

Populus spo - exige solos férteis.

Prosopis juliflora (algaroba) - para clima semi-árido.

Maclura pomifera - ELA

Acacia spp - India e Africa Tropical

Robinia pseudoacacia - URSS e Bulgária.

Juniperus spp

Caragana arborescens - para clima muito frio. 


\subsection{Grevillea robusta}

A Grevillea robusta A. Cunn., comumente designada "silk oak" (carvalho prateado), é uma espécie arbörea da famîlia Proteaceae, que chega a atingir 35m de altura (NATIONAI ACADEMY OF SCIENCES, 1980) e $80 \mathrm{~cm}$ de DAP (BAGGIO, 1983).

Originăria das áreas costeiras subtropicais de New south Wales e Queensland, esta espécie australiana foi introduzida em são Paulo no final do século passado (BAGGIO, 1983), estando bem aclimatada ao Brasil (CORREA, 1926).

Cultivada com sucesso nas regiões tropicais da Åfrica e em outras regiões de clima quente através do mundo, encontram-se ärvores de Grevillea desde o nível do mar até $2.300 \mathrm{~m}$ de altitude (NATIONAL ACADEMY OF SCIFNCES, 1980), em climas temperados e tropicais, passando pelo subtropical e semi-árido. A espécie vegeta tanto en locais com 400 a $600 \mathrm{~mm}$ de precipitação anual, com seis meses secos (NATIONAL ACADEMY OF SCIEN CES, 1980), como em locais com até 3.000m de chuva anual, como a costa Rica (CORREA, 1926). Segundo a NATIONAL ACADEMY OF SCIENCES (1980), a Grevillea robusta suporta temperatura de até -10.C, resistindo, portanto, às geadas.

A espécie tem raízes pivotantes e se adapta bern a muitos típos de solo, desde arenosos, argilosos de fertilidade mëdia, e solos ácidos. Prefere solos profundos e não tolera solos encharcados (NATIONAL ACADEMY OF SCIENCES, 1980).

No norte do Paraná esta espécie tem apresentado um bom crescimento, com incremento médio anual de $1,7 \mathrm{~m}$ em arenito e $2,0 \mathrm{~m}$ em terra roxa (BAGGIO, 1983). En São Paulo, KOSCINSKI (1938) obteve incre mento em altura de $1,75 \mathrm{~m} /$ ano."

A folhagem da Grevillea è levemente decídua no inverno, não perdendo nunca a totalidade de suas folhas.

Com o sistema reprodutivo um tanto controvertido (de polinização cruzada, segundo MORAIS, 19.82; monóica, segundo hoNG Jr., 1974, e hermafrodita, preferindo ou não excluindo a autofecundação, segundo KOSCINSKI, 1938), de qualquer maneira a Grevillea sementeia abundante mente já aos cinco anos de idade, e apresenta regeneração natural mi- 
to fácil, podendo se tomar praga. No entanto, uma vez cortada, não apre senta rebrota (NATIONAL ACADEMY OF SCIENCES, 1980).

Util para marcenaria, apicultura e lenha, a Grevillea ē usada mais freqlentenente associada às lavouras de café, chá e cacau, co mo sombreadora ou quebra-vento (CHILD e SMITH, 1960, WILLEY, 1975; SCHIE BER e ZENTMYER, 1978 e BAGGIO, 1983).

Nas regiões onde tem sido cultivada, tên sido detectadas algumas pragas e doenças e outros problemas, a saber:

- saūva (Atta sexdens L.): ataca os plantios en São Paulo, provocando a morte de algumas ärvores (MELIO, 1959);

- falhas em oH inferior a 4,2 (CHHD e SMTH, 1960), apresentando alta concentração de Manganês nas plantas mortas;

- cochonilhas ( CORREA, 1926): Asterolecanium pustulans, Icerya purchasi e Monophlebius nivens;

- "dieback" decorrente da deficiência de Boro (SMITH, 1960);

- cancro do tronco (Botryosphaeria dothidea) entre 1.300 e $1.800 \mathrm{~m}$ de altitude na Guatemala e gomose e morte regressiva das ārvores na flörida (SCHIEBER e ZEINTMYER, 1978);

- redução no crescimento apōs 20 anos en solos secos (NATIONAL ACADEMY OF SCIENCES, 1980);

- lagarta desfolhadora Geometrydae (BAGGIO, 1983).

O que se verifica é que, na prática, a Grevillea robusta se aproxima bastante da espécie teörica idealizada como quebra-vento. Apresenta bom crescimento, forma e porosidade convenientes, não é caduci fölia e retém os ramos inferiores, além de se desenvolver bem em diversos tipos de solo e ser resistente à geada. Ein relação a pragas e doenças, cabe ressaltar o problema da saúva, especialmente em são Paulo e a gomose do tronco*, que pode levar à morte as ārvores de Grevillea.

* Alceu de Arruda Veiga, informação pessoal. 
3 - MATERTAL E METODOS

\subsection{Local}

Foram efetuadas medições em três municípios do Vale do Paranapanema, caracterizados na tabela 1.

o vento dominante no Vale do Paranapanema é o vento dudeste, um vento frio que tem origem no polo sul e que tem nos meses de maio a outubro sua maior intensidade (CAMARGO, 1965/66).

Estes ventos, segundo a escala Beaufort de força do vento (JEMISON, 1934), são leves e raramente fogen das faixas 1 e 2, daquela escala, com velocidade entre 1,6 e 11,2km/h. Apesar de leves, podem prejudicar seriamente as culturas agrícolas da região, principalmente os cafezais (CAMARGO, 1965/66). Esporadicamente, ocorrem vendavais, que chegam a atingir 100km/h, no início da época das chuvas, que podem acarretar grandes danos.

A rede de drenagem do Vale do Paranapanema é do tipo retan gular, corn a maior parte dos cursos d'água correndo no sentido norte-sul. 
Tabela 1. Caracterização dos locaís de coleta de dados.

\begin{tabular}{|c|c|c|c|}
\hline & \multicolumn{2}{|r|}{$\begin{array}{llllll}M & U & N & I & C & I\end{array}$} & \multirow[b]{2}{*}{ Porecatu(PR) } \\
\hline & Cambará (PR) & Cândido Mota(SP) & \\
\hline Latitude (Sul) & $23.02^{\prime}$ & $22 \circ 45^{\prime}$ & $22 \circ 45^{\prime}$ \\
\hline \multicolumn{4}{|c|}{ Longitude (W de Green- } \\
\hline wich) & $50906^{\prime}$ & $502^{\prime} 3^{\prime}$ & $51.23^{\prime}$ \\
\hline Solo (BRASIL, 1971) & TRe & IR & TRe \\
\hline Clima (NIMER, 1979) & \multicolumn{3}{|c|}{$\begin{array}{l}\text { Tropical, Sub-quente, superúnido, com } \\
\text { subseca }\end{array}$} \\
\hline $\begin{array}{l}\text { Precipitação média } \\
\text { anual (NIMER, 1979) }\end{array}$ & $1250 \mathrm{~mm}$ & 1250mun & $1250 \mathrm{~mm}$ \\
\hline $\begin{array}{l}\text { ocorrência média de } \\
\text { geadas (vezes/ano). }\end{array}$ & & & \\
\hline (NIMER， 1979l & $3-5$ & $3-5$ & $3-5$ \\
\hline
\end{tabular}




\subsection{Pontos de Mediçäo}

Todas as medições forarn efetuadas em diferentes distâncias do quebra-vento, conforme esquematizaōo na figura 5.

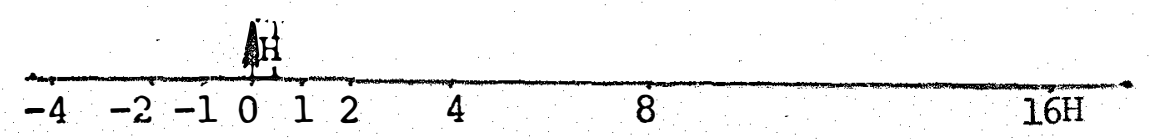

Figura 5 - Representação esquernática dos pontos de redição.

As distâncias foram estabelecidas em termos de múltiplos de H (altura da barreira), conforme recomendado por BATES (1944). A altura das árvores foì determinada com um hipsômetro de Weise e transportada para a horizontal com o auxîlio de una trena.

\subsection{Caracterização dos quebra-ventos.}

As medições foram efetuadas em cinco quebra-ventos diferentes:

A- quebra-vento de 6 anos de idade, localizado no município de Porecatu (PR), com 10m de altura, duas linhas, distância de $6 m$ dentro da linha e $6 \mathrm{~m}$ entre linhas, com desrama até $2 \mathrm{~m}$;

B- em Porecatu (PR), com 10m de altura e 6 anos de idade, uma única linha, distância de $6 \mathrm{~m}$ entre árvores, desrama até $2 \mathrm{~m}$;

C- en Porecatu (PR), com lom de altura, 6 anos de idade, unilinear, espaçamento de $5 \mathrm{~m}$ entre ärvores, desrama até $2 \mathrm{n}$;

D- no município de Cândido Mota (SP), com 5m de altura, e dois anos e meio de idade, unilinear, 5m entre árvores, sen desrama;

E- en Cambará (PRl, com lom de altura e 10 anos, unìlinear, lom entre ârvores, desrama até $2 m$.

Os quebra-ventos utilizados são perpendiculares ao vento dominante, formados por árvores de Grevillea robusta. 
Para cada quebra-vento determinou-se o incremento médio anual (altura/idadel, a relação entre altura e diâmetro da copa das árvores (média de 5 ărvoresl e a permeabilidade. Este ültimo parâmetro foi subdividido en porosidade (ou permeabilidade) das copas - correspondente á porcentagem de poros existente no espaço visual ocupado pelas copas das árvores - e porosidade da barreira - correspondente à permeabilidade total - que é a soma dos poros das copas mais as falhas e os vãos existentes entre as ärvores. Para detenuinação da permeabilidade adotou-se a metodologia de BRONN e ROSENBERG (1972).

\subsection{Mediç̃es de velocidade do vento}

As medições de velocidade do vento foram efetuadas nos quebra-ventos A, B, C e D. Utilizou-se o seguinte material: 2 anemônetros Casella de canecas, montados en suporte móvel (esquematizado na figura 6-A), e um crôânetro.

0 tempo de medição adotado foi de 30min. para cada ponto, segundo recomendação de SEGUIN e GIGNOUX (1974).

Mediu-se simultaneamente a velocidade do vento na área protegida e em campo aberto e estabeleceu-se a velocidade em cada ponto como sendo a porcentagem da velocidade obtida no ponto em relação à velocidade do vento, no mesmo espaço de tempo, na ausência de proteção, conforme recomendado por BATES (1911).

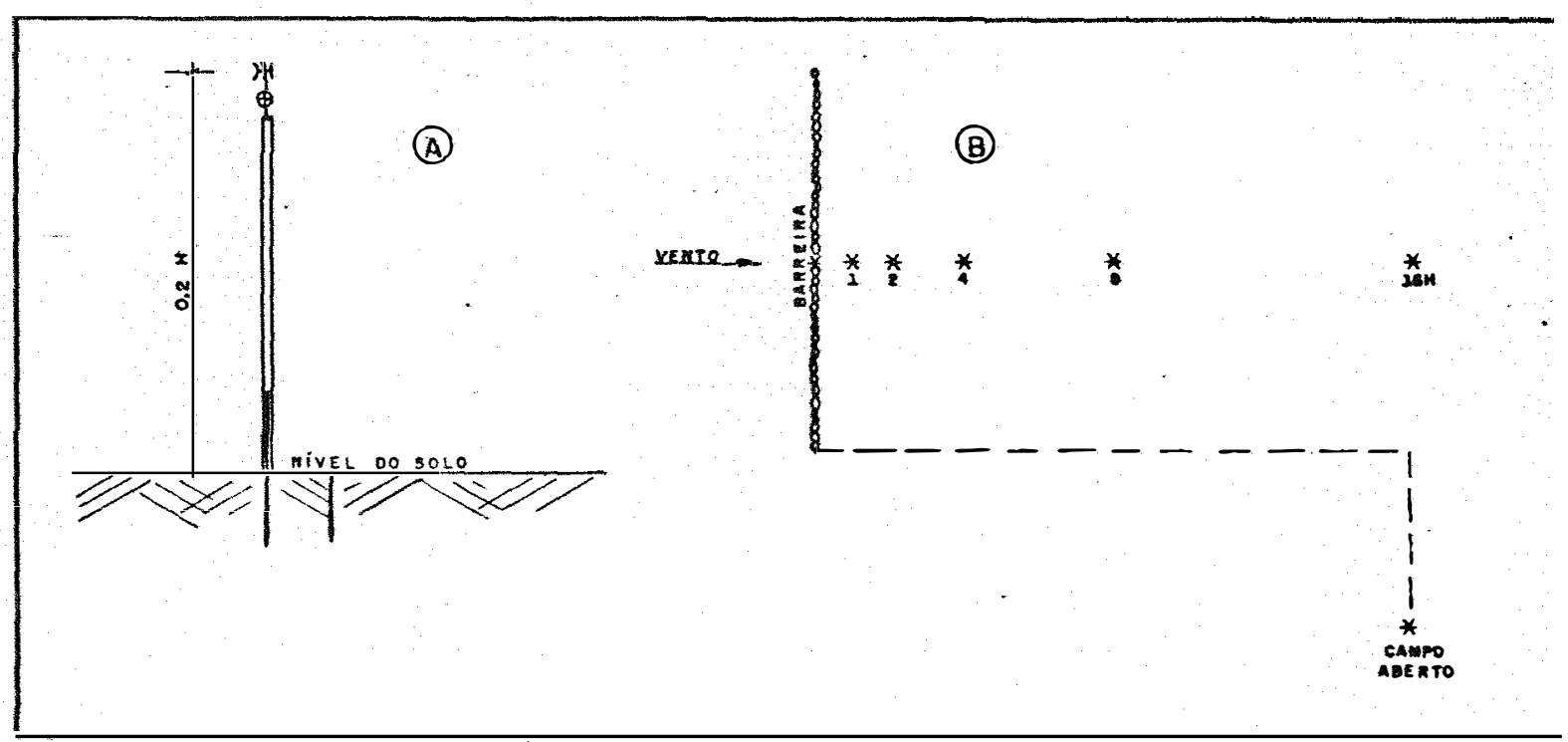

Figura 6 - Esquema de instalação dos anemônetros no campo. 
Os aremônetros foram instalados a uma altura correspondente a $0,2 \mathrm{H}$ acima do nîvel do solo.

A velocidade do vento en campo aberto foi tomada a $16 \mathrm{H}$, a $50 \mathrm{~m}$ de distância do inî́cio da barreira, conforme esquematizado na figura $6(\mathrm{~B})$.

As medições de velocidade do vento foram efetuadas no mês de agosto, quando o Vale do Paranapanema é mais atingido pelo vento. No perĩodo de medição a velocidade absoluta do vento variou entre 4,2 e 10,4 Km/h, ficando, na média, en tomo de $7,6 \mathrm{~km} / \mathrm{h}$.

\subsection{Medições de umidade do solo}

Para estudo do efeito do quebra-vento sobre a umidade do solo foi utilizado o quebra-vento D. Para a coleta das amostras utilizaram-se dois trados. As amostras foram colocadas em saquinhos plásticos devidamente vedados e depois transferidas para latinhas de alumínio para serem levadas à estufa.

Determinou-se a umidade do solo na camada superficial (0$10 \mathrm{~cm})$ e em uma camada mais profunda $(30-40 \mathrm{~cm})$. Para comparação, tomaram se amostras em campo aberto, a $16 \mathrm{H}$ e a $20 \mathrm{~m}$ de distância da extremidade da barreira.

Tomaram-se três amostras para cada ponto, nas distâncias $0,1,2,4,8$ e $16 \mathrm{H}$, a sotavento.

As amostragens foram efetuadas no mês de julho, onze dias após uma chuva de $26,6 \mathrm{~mm}$, e a velocidade média do vento desde esta chuva até a data da medição foi de $2,78 \mathrm{~km} / \mathrm{h}$ (tomada no posto meteorológico mais próximo - a cerca de $5 \mathrm{Km})$.

A umidade do solo foi calculada em termos de $\%$ do peso seco (em estufa, a 105\%C, durante 48 horasl.

3.6. Medições de produção de café.

Para avaliação do efeito do quebra-vento a produção de ca- 
fê utilizou-se o quebra-vento $\mathrm{E}$.

Foram coletadas amostras nos pontos $0,1,2,4,8$ e 16H, a sotavento. Não foi possîvel obter amostras em campo aberto, visto que a lavoura estudada era totalmente protegida por quebra-ventos.

Para cada ponto foram tomadas 5 amostras, cada uma delas correspondente à prođução de dois pés de café (uma coval. Mediram-se ain da a altura e o diânetro da copa dos cafeeiros, visando correlacionar o estudo vegetativo com a produtividade e a proteção pelo quebra-vento.

As amostras de café foram secas ao ar durante vinte dias após a colheita e pesadas individualmente. 
4 - RESULtadas E DISCUSSÃO

4.1. Caracterização dos guebra-ventos.

Figura 2. - Caracterização dos quebra-ventos

\begin{tabular}{|c|c|c|c|c|c|c|}
\hline & IMA & NO DE & $\%$ & POROSIDADE & POROSIDADE & ALTURA/ \\
\hline QUEBRA- & & LINHAS & $\mathrm{DE}$ & DAS COPAS & DA BARREIR & IARGURA \\
\hline VENTO & (m/ano) & & VÃOS & $\left(\frac{8}{6}\right)$ & $\mathrm{RA}$ (\%) & $D A C O P A$ \\
\hline A & 1,67 & 2 & 28 & 10 & 35 & 2,74 \\
\hline B & 1,67 & 1 & 41 & 26 & 56 & 2,20 \\
\hline$C$ & 1,67 & 1 & 33 & 20 & 46 & 2,13 \\
\hline $\mathrm{D}$ & $2,0.0$ & 1 & ag & 20 & 27 & 1,89 \\
\hline$E$ & 1,00 & 1 & 50 & 19 & 61 & 1,79 \\
\hline
\end{tabular}


Visto que os quebra-ventos que têm sido utilizados no vale do Paranapanema são nozmalmente constituỉdos de apenas uma ou, no mäximo, duas linhas, não foi possível a comparação entre värios tipos quanto a es te aspecto. O que se observou foi que, conforme afirma GUYOT (1963), o número de linhas é irmportante na medida em que afeta a permeabilidade a esta sim é que irá deteminar o padrão de interferência da barreira no fluxo do vento.

As ärvores de Grevillea apresentam uma porosidade média, ho mogênea em toda a copa, de $23 \%$. Quando se planta um quebra-vento de duas linhas, a sobreposição das copas faz com que esta porosidade seja reduzida a $10 \%$. E uma porosidade baixa, que resultaria em um quebra-vento pouco permeävel se não houvessem falhas na barreira.

A condução da porosidade ideal se faz através da escolha do espaçamento entre as árvores dentro da linha, que resultará em um maior ou menor entrelaçamento entre as copas, conforme seja mais estreito ou mais largo este espaçamento.

Quebra-ventos multilineares são interessantes quando há intenção de exploração da madeira. Não é o caso dos quebra-ventos de Grevillea robusta no Brasil. Aqui, eles são plantados com a finalidade de proteger as lavouras e, ao mesmo tempo, melhorar a paisagem, não havendo, regra geral, interesse em utillização econômica das árvores. Assim, não são encontrados quebra-ventos com mais de uma linha, a não ser junto às. estradas, onde não há perda de espaço.

Além da relação com o número de linhas, há um outro aspecto a ser levado em conta em relação à permeabilidade dos quebra-ventos: a presença de "falhas" ou "vãos" na barreira, indesejável segundo diversos autores (BATES, 1944; FERBER, 1958; GUYOT, 1963; EATON, 1971; GOMES, 1972 e BOTTOMLEY e PARKER, 1974). Quando o espaçamento entre árvores é muito largo, forman-se vãos entre as árvores. As barreiras de Grevillea se fecham (as oopas se entrelaçam) quando a altura atinge cerca de duas vezes o espaçamento. Se o espaçamento for de $10 \mathrm{~m}$, como é o caso do quebra-vento $\mathrm{E}$, isto só ocorrerá quando as ârvores atingirem $20 \mathrm{~m}$ de altura, o que dificilmente acontece com a Grevillea robusta à plena luz (o que se tem observado é que, nestas condições, esta espécie dificilmente ultrapassa os 
15m). Neste caso, sempre existirão falhas verticais na barreira, que provocarão o afunilamento do vento.

A desrama, normalmente praticada em quebra-ventos para lavouras de cafẻ com a finalidade de reduzir os riscos de geada (IBC., 1981), também provoca o afunilamento do vento. Os quebra-ventos A,B, e C foram desramados. Gorn exceção de A, composto por duas linhas, os outros dois quebra-ventos desramados apresentaram aumento da velocidade do vento no ponto $\mathrm{OH}$ (na linha das ärvoresi, sendo que no quebra-vento $\mathrm{B}$ a velo cidade neste ponto foi $4 \%$ superior à velocidade em campo aberto, tomando - o ineficaz na faixa contígua à Jarreira.

\subsection{Velocidade do vento}

Na tabela 3 são apresentados os valores relativos da velo cidade do vento em diferentes distâncias da barreira, dados en porcentagem da velocidade em campo aberto, tomada simultaneamente. Estes valores estão representados na figura 7 .

Tabela 3 - Velocidade do vento (\% em relação ao campo aberto' em diferen tes distâncias da barreira.

\begin{tabular}{lcccc}
\hline $\begin{array}{l}\text { DISTÂNCIA } \\
\text { DA BARREIRA } \\
\text { (múltiplos } \\
\text { de altura H) }\end{array}$ & $\mathrm{Q}$ U $\mathrm{E}$ B $\mathrm{R}-\mathrm{V}$ A $\mathrm{N}$ O S \\
\hline$-4 \mathrm{H}$ & $\mathrm{A}$ & $\mathrm{B}$ & $\mathrm{C}$ & $\mathrm{D}$ \\
\hline$-2 \mathrm{H}$ & - & - & - & 88,3 \\
\hline$-1 \mathrm{H}$ & 90,5 & 96,7 & 65,4 & 85,0 \\
\hline 0 & 87,5 & 93,1 & 48,7 & 75,7 \\
\hline $1 \mathrm{H}$ & 51,0 & 104,0 & 60,0 & - \\
\hline $2 \mathrm{H}$ & 43,3 & 81,6 & 48,4 & 67,1 \\
\hline $4 \mathrm{H}$ & 28,2 & 69,2 & 42,6 & 54,6 \\
\hline $8 \mathrm{H}$ & 36,5 & 64,0 & 58,5 & 37,8 \\
\hline $16 \mathrm{H}$ & 60,2 & 68,2 & 87,3 & 62,6 \\
\hline
\end{tabular}




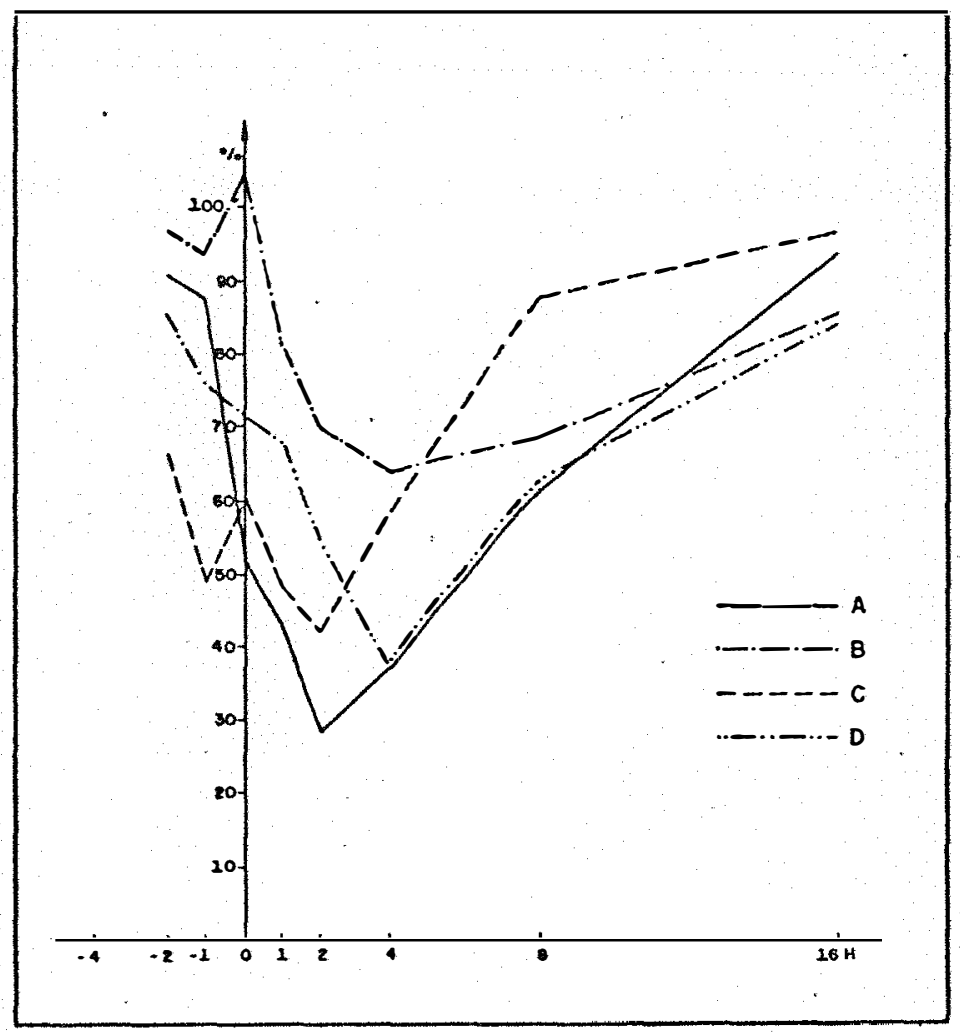

Figura 7- Velocidade do vento (\% em relação ao campo aberto) em diferen tes distâncias da barreira, para quebra-ventos de diferentes permeabilidades: $A=35 \%, B=56 \%, C=46 \%$ e $D=27 \%$.

A fig. 7 mostra que os quebra-ventos de Grevillea robusta agem reduzindo a. velocidade do vento a barlavento e a sotavento. Para as quatro barreiras avaliadas ( A, B, C e D) este efeito ultrapassou as faixas de $2 \mathrm{H}$ a barlavento e $16 \mathrm{H}$ a sotavento, sendo que a intensidade e o padrão de interferência sobre o fluxo do vento foram diferentes para barreiras de diferentes permeabilidades.

O quebra-vento A, com 10\% de porosidade das copas e o quebra-vento B, com 26\%, confirmam a observação de SKIDMORE (1976) e REDDY (1979), de que uma barreira muito densa proporciona maior proteção para uma menor distância e que uma barreira pouco densa proporciona menor proteção para uma maior distância. Cơn uma redução na velocidade do 
vento cerca de 30\% superior no ponto de mäxima proteção, o quebra-vento A, menos permeável, passa a ser menos efetivo que o quebra-vento B a partir de $12 \mathrm{H}$, sendo que em $16 \mathrm{H}$ o quebra-vento $\mathrm{B}$ formece $10 \%$ a mais de proteção que o primeiro.

O ponto dé mãxima proteção foi mais próximo da barreira

(2H) para a barreira mais compacta (A) e mais distante (4H) para a bar reira mais permeável (B), considerando-se a porosidade das copas. Este é urn aspecto importante e deve ser analisado juntamente com a competição, pois uma boa proteção contra o vento junto às árvores pode ser anu lada pelos efeitos negativos da competição. Na verdade, os efeitos bené ficos dos quebra-ventos passan a ser detectáveis a partir do ponto onde cessa a competição das ārvores om a cultura, ou seja, 2H para quebraventos de Grevillea robusta.

Comparando-se a área protegida e a intensidade de proteção oferecida pelas barreiras estudadas, verifica-se que os . quebraventos A e D são os mais eficientes. São os menos permeáveis e, principalmente, os mais homogêneos, com menor porcentagem de "vãos". O quebra-vento $\mathrm{D}$ apresenta duas vantagens em relação ao A: tem uma única linha (menor custo e menor perda de espaço) e oferece maior proteção nas faixas mais distantes (a partir de 9H), onde os ganhos são reais, não sendo anulados pela competição.

Considerando, segundo IEYTON (1983) que a área protegida é aquela en que a velocidade do vento é reduzida em pelo menos $20 \%$, temos que os quebra-ventos estudados protegem aproximadamente as seguintes faixas: $A=12,5 \mathrm{H} ; B=13 \mathrm{H} ; C=7,0 \mathrm{H}$ e $\mathrm{D}=14,0 \mathrm{H}$, dados estes obtidos a partir da extrapolação das curvas da fig. 7. Lembrando que a distância entre as barreiras é função da faixa protegida, deduzimos que o quebra-vento D, com $27 \%$ de permeabilidade total, não desramado, é o que protege a maior área, podendo ser instalado com um maior intervalo entre barreiras, com imolicações de ordem econômica.

\subsection{Competição por Iuz}

As ärvores competem por fatores ambientais can a cultura. o 
grau e a extensão dos efeitos da competição variam com as condições ambientais, com a espeécie cultivada e com as características do quebravento, como: espécie utilizada e orientação.

No que diz respeito à competição por luz, os quebra-ven tos de Grevillea não tên causado perdas por dois motivos: primeiro, por que a cultura protegida, o café, é tolerante à sombra e tem sido cultivado até mesmo junto às árvores do quebra-vento, com boa produção; e, segundo, porque dada a direção do vento dominante no Vale do Paranapane ma (sudeste, cơn um pequeno ângulo en relação ao leste), os quebra-ventos têm sido implantados muito próximos da direção norte-sul que, segun do diversos autores (GUYOT, 1963 e BROWL e HALL, 1968), é a que causa menos problemas de sombreamento.

E interessante observar que, alëm de ser perpendicular ao vento dominante na região, a linha norte-sul coincide, na maioria das vezes, com as curvas de nivel, devido às caracteristicas da rede de dre nagem. Desta forma, os quebra-ventos podem obedecer a melhor orientação e, ao mesmo termo, ser plantados em nível, auxiliando no controle da ero são do solo e não interferindo na mecanização das lavouras.

\subsection{Umidade do solo}

A umidade do solo em diferentes distâncias da barreira, tomada na camada superficial do solo $(0-10 \mathrm{~cm})$ e en uma camada :mais rrofunda (30 - 40cm), está relacionada na Tabela 4. Determinou-se a unidade real, em porcentagem do peso seco, e a água uisponível, em porcentagem da quantidade máxima de água disponível para o Latossol Roxo em cada profundidade.

Para deteminação da quantidade de água disponỉvel utilizou-se a seguinte fórmula:

$$
A D=\frac{\left(U_{R}-U_{P M P}\right) \quad 100}{U_{C C}-U_{P M P}}
$$


onde:

$\mathrm{AD}=$ água disponivel en porcentagem da capacidarle de àgua disponível (CAD) para o Latossol Roxo.

$\mathrm{U}_{\mathrm{R}}=$ umidade da amostra:

$\mathrm{U}_{\mathrm{CC}}=$ umidade do Latossol Roxo na capacidade de Campo $(0 ; 1$ bar $)$.

$\mathrm{U}_{\mathrm{PMP}}=$ umidade do Latossol Roxo no Ponto de Murcha Permanente $(15,0$ war $)$

Tabela 4 - Umidade real (em \% do peso seco) e água disponivel (em \% da CAD) a 0-10 e a 30-40 cm de profundidade.

DIST. DA - UMTDADE REAL $(\%)$ AGUA DISPONIVIVL (\% CAD)

BARREIRA $0-10 \mathrm{~cm} \quad 30-40 \mathrm{~cm} \quad 0-10 \mathrm{~cm} \quad 30-40 \mathrm{~cm}$

$\begin{array}{llll}0 & 25,5 & 30,4 & 23,5\end{array}$

\begin{tabular}{ccccc}
\hline IH & 26,5 & 32,4 & 33,7 & 72,5 \\
\hline $2 \mathrm{H}$ & 26,8 & 33,6 & 36,7 & 84,3 \\
\hline $4 \mathrm{H}$ & 27,4 & 35,2 & 42,9 & 100,0 \\
\hline $8 \mathrm{H}$ & 27,4 & 34,7 & 42,9 & 95,1 \\
\hline $16 \mathrm{H}$ & 26,4 & 34,1 & 32,7 & 89,2 \\
\hline Campo Aberto & 26,1 & 33,2 & 29,6 & 80,4 \\
\hline
\end{tabular}

Os dados de ãgua disponível estão representados graficamen te na figura 8. 


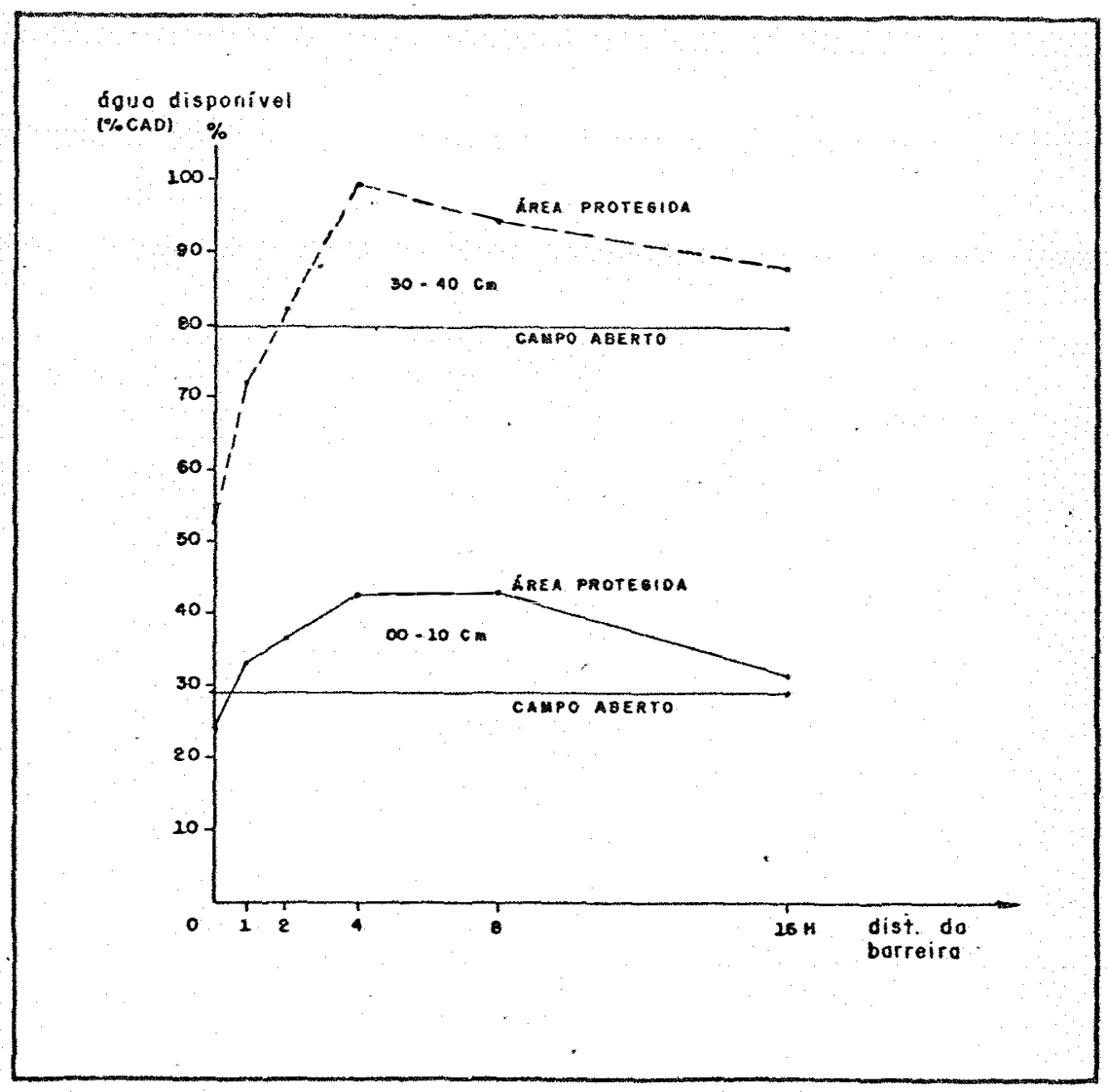

Figura 8 - Água disponîvel no solo en diferentes distâncias da barreira, a 0-10 e, 30-40 cm de profundidade.

Os dados referentes à umidade do solo (tab. 4 e figura 8) mostram que pode haver concorrência por água junto às árvores. A redução no teor de umidade é muito pequena e atinge uma faixa muto estreita (de cerca de $0,5 \mathrm{H}$ ) na camada superficial do solo, mas é mais intensa e se estende até as proximidades de $2 \mathrm{H}$ para a camada de 30 a $40 \mathrm{~cm}$ de profundidade.

Nota-se que o efeito do quebra-vento sobre a umidade "do" solo é mais visível nas camadas mais profundas, sendo que aí tanto os ganizos quanto as perdas são maiores, provavelmente devido à maior concentração radicular nestas camadas.

A Fig. 8 mostra que a barreira age evitando as perdas de água do solo em uma faixa que ultrapassa $16 \mathrm{H}$, sendo que este efeito $\ddot{e}$ 
mäximo entre 4 e $8 \mathrm{H}$.

Confrontando-se as perdas e os ganhos em termos de umidade do solo verifica-se facilmente que os quebra-ventos arbôreos são benéficos à cultura, especialmente àquelas mais suscetíveis à falta de uridade.

\subsection{Produção de café}

A produção de café en diferentes distâncias do quebravento está relacionada na tabela 5 e fig. 9, sendo dada em termos de Kg. de caié seco/cova.

A altura e o diâmetro da copa dos cafeeiros amostrados, com as respectivas produções, em Kg/cova, são apresentados na tabela 6 .

Tabela 5. Produção de café seco (Kg/cova), en diferentes distâncias do quebra-vento.

\section{DISTÂNCIA}

DA BARREI

RA (Mülti

plos de $\mathrm{H}$ )

A MOSTRAS

$I$ II III

IV

$\mathrm{V} \quad \overline{\mathrm{X}} \quad \mathrm{x}$

C.V.

웅

\begin{tabular}{llllllllll}
\hline 0 & 1,38 & 0,92 & 1,31 & 0,65 & 2,50 & 1,35 & 0,71 & 52,3 \\
\hline $1 \mathrm{H}$ & 0,76 & 0,57 & 0,69 & 0,80 & 1,12 & 0,79 & 0,21 & 26,0 \\
\hline $2 \mathrm{H}$ & 0,44 & 0,66 & 0,55 & 1,18 & 1,25 & 0,82 & 0,37 & 45,7 \\
\hline $4 \mathrm{H}$ & 1,54 & 2,25 & 1,43 & 2,22 & 1,38 & 1,76 & 0,43 & 24,6 \\
\hline $8 \mathrm{H}$ & 1,46 & 0,93 & 1,18 & 1,75 & 2,88 & 1,64 & 0,76 & 46,2 \\
\hline $16 \mathrm{H}$ & 1,45 & 1,82 & 1,86 & 1,07 & 1,92 & 1,62 & 0,36 & 22,2 \\
\hline
\end{tabular}


Tabela 6. Altura (m), diâmetro da copa (m) e produção de café seco (Kg/ cova) - dados mêdios para as diferentes distâncias do quebravento.

\begin{tabular}{|c|c|c|c|c|c|c|}
\hline \multirow[b]{2}{*}{ CAFEEIRO: } & \multicolumn{6}{|c|}{ DISTÂNCIA DA BARREIRA ( múltiplos de H) } \\
\hline & 0 & $1 \mathrm{H}$ & $2 \mathrm{H}$ & $4 \mathrm{H}$ & $8 \mathrm{H}$ & $16 \mathrm{H}$ \\
\hline ALTURA (m) & 2,40 & 2,37 & 2,50 & 2,52 & 2,37 & 2,40 \\
\hline \multicolumn{7}{|l|}{ DIÂMETRO ḊA } \\
\hline COPA (m) & 2,12 & 2,62 & 2,72 & 2,58 & 2,46 & 2,48 \\
\hline \multicolumn{7}{|l|}{ PRODUÇÃO } \\
\hline (Kg/cova) & 1,35 & 0,79 & 0,82 & 1,76 & 1,64 & 1,62 \\
\hline
\end{tabular}

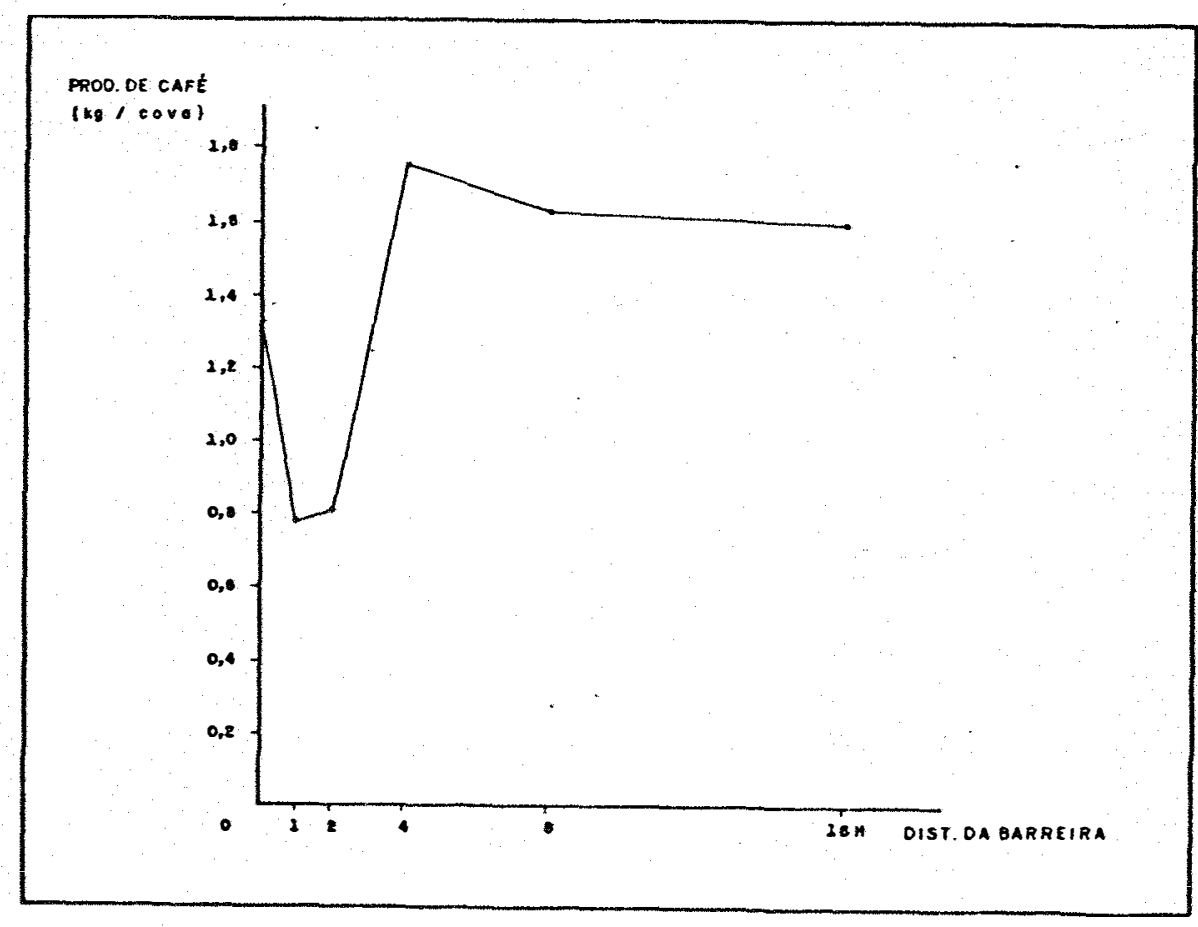

Figura 9. Produção de café seco, em Kg/cova, em diferentes distâncias do quebra-vento. 
A variação de produção de um cafeeiro para outro è muito grande e não está correlacionada com o volume da copa. A curva de altụ ra mëdia dos cafeeiros acompanha a curva de produção média, mas quando se analissa individualmente as plantas, esta correlação deixa de existir.

Com a inexistência dos dados de produção do cafeeiro sem proteção contra o vento, não hâ como avaliar os ganhos e perdas reais decorrentes dos quebra-ventos. Para efeito de comparação, adotou-se a produção en 16H como média.

Verifica-se que há uma queda de produção até as proximidades de $2 \mathrm{H}$, provavelmente decorrente da competição radicular. A eleva da prođução no ponto 0 (sob as árvores da barreira) pode ser explicada pela menor cormpetição por água e luz neste ponto, jā que as ārvores foram plantadas ao lado de um carreador e as plantas amostradas recebíam luz solar em toda a altura até às 10hs. da manhã, além de sofrerem competição radicular com outros cafeeiros apenas de um lado.

A produção máxima observada ocorreu entre 4 e 8H, sendo que em $4 \mathrm{H}$ foi $8,6 \%$ superior à produção em $16 \mathrm{H}$, para o café seco.

Dos dados levantados depreende-se que a ação dos quebraventos é intensa até $8 \mathrm{H}$, mas que os benefícios são restritos nas áreas mais prōximas da barreira, devido à competição. Assim, a produção dos cafeeiros è mäxima entre 4 e 8H, coirncidindo com o pico da curva de umidade do solo e com a redução máxina da velocidade do vento para que bra-ventos permeáveis. No entanto, diante do alto coeficiente de varia ção encontrado entre as amostras, seria necessāria uma amostragem muito maior (vide ậendice, item 7.5.), para confirmação destas observa ções.

4.6. Implantação e manejo dos quebra-ventos.

Diante do interesse em obter os efeitos dos quebra-ventos no mais curto espaço de tempo, práticas destinadas a estimular o crescí mento das árvores podem ser adotadaśs,como abertura de covas grandes: , fertilização nas covas quando as condições de fertilidade não forem 
adequadas e utilização de mudas grandes e bem formadas.

A desrama das árvores deve ser evitada e devem ser tomadas outras medidas visando a obitenção de barreiras de permeabilidade homogênea e sem falhas, a saber: replantio das mudas mortas logo após o plantio e combate permanente à formiga saúva (Atta spp), que além de desfolhar totalmente as árvores, pode chegar a causar a morte de ärvores adultas através de ataques sucessivos. 


\section{CONCLUSÕES}

Os quebra-ventos de Grevillea robusta dos tipos A, B, C, e D provocam redução na velocidade do vento em uma faixa ciue ultrapassa $2 \mathrm{H}$ a barlavento e $16 \mathrm{H}$ a sotavento.

Os quebra-ventos densos, pouco porosos, são mito eficien tes na redução da velocidade do vento junto à barreira, mas a proteção se estende por uma distância relativannente curta. Por outro lado, os quebra-ventos porosos fornecem menor redução na velocidade do vento jun to à barreira, mas protegem as culturas por uma distância bern maior, comparativamente aos primeiros.

Considerando-se o grau de proteção e a extensão da área protegida, verifica-se que o quebra-vento $D$, cam $27 \%$ de permeabilidade e com a menor porcentagem de "vãos", foi o mais eficiente na proteção contra o vento.

As barreiras protegem a cultura rechuzindo as perdas de umidade do solo, sendo que este beneficio se faz sentir a partir de $2 \mathrm{H}$ e se estende alêm de 16H, sendo máximo entre 4 e $8 \mathrm{H}$. En termos de umidade do solo, os ganhos superam as perdas.

Sob o aspecto de proteção contra o vento a desrama das 
árvores da barreira é contra-indicada, pois provoca afunilamento do vento, que passa pela base das ärvores com a velocidade aumentada. No entanto, alguns autores recomendam que, a despeito deste afunilamento, a desrama deve ser feita nas regiöes en que as geadas sejam freqlentes. Para proteger lavouras no Vale do Paranapanema, os quebra-ventos de Grevillea robusta podem ser plantados com uma única linha, ârvores espaçadas em 5m entre sì, e a distância entre duas barreiras consecutivas deve ficar en tomo de 14H. Cono a altura máxima que a Grevillea atinge em campo abierto girra em torno de 15m, esta distân cia deve ser de, no mäximo, 200in, para que haja proteção efetiva. 
6. IITERATURA CITADA

AASE, J.K.; F.H. SIDDOWAY e A.I. BIACK, 1976. Perenial grass barriers for wind erosion control, snow management and crop production. In: TINUS, R.W., Ed. Shelterbelts on the Great Plains: Proceedings of the Symoosium. Denver, Great Plains Agricultural Council, 69-78.

ANDERSON, P.O., 1935. Planting the standard windbreak. Univ. of Minneso ta Agric. Ext. Div. 8p. (Special Bulletin, 168).

ANDRADE, M.C. de, 1979. Agricultura e Capitalismo. São Paulo, Livraria Editora Ciências Humanas. 115p.

BAGGIO, A.J., 1983. Sistema agroflorestal grevílea x café: início de nova era na agricultura paranaense? Curitiba, EMBRAPA-URPFCS. 15p. (Cir cular Técnica, 09).

BATES, C.G., 1911. Windbreaks: their influence and value. Washington USDA. 100p. (For. Serv. Bull: 86).

BATES, C.G., 1944. The windbreak as a fam asset. Washington, 22p. (Far mer's Bull. 1405). 
BOINOMLEY, G. e N. PARKER, 1974. Shelter. Tasmanian Joumal of Agriculture $(s .1) ..45(2): 92-99$.

BOUCHET, R.J.; S. de PARCEVAUX e J. ARNOUX, 1963. Amélioration du rendement des végetaux par abaissement de l'evapotranpiration potentielle. Ann. Agron. 14 (5) : 825-834.

BRASII, 1971. Levantamento de Reconhecimento dos Solos do Nordeste do Estado do Paraná. Curitiba, Depto. Nac. de Pesquisa Agropecuäria, Div. de Pesquisa Pedológica 144p. (Boletim Técnico, 16).

BRAUN-BLANQUET, J. , 1950. Sociologia Vegetal. Buenos Aires, Acme, 444p.

BROWN, A. e N. HALL, 1968. Growing trees on australian fams. Canberra, Forest and Timber Bureau. 397p.

BROWN, K.W., e N.J. ROSENBERG, 1972. Shelter effects on microclimate, growth and water use by irrigated sugar beets in the Great Plains. Agric. Meteorol., Amsterdan, 9: 241-263.

CABORN, J.M., 1962: Shelterbelt research. In: Forestry Commission Report on Forest-Research for the Year Ended. Iondon, Her Majesty's stationery office, p: 113-116.

CAMARGO, A.P.de, 1960. Instruções para o combate à geada em cafezais. o Agronômico, Campinas, 12: 21-35.

CAMARGO, A.P. de, 1965/66. Quebra-vento quebra o galho. Guia Rural.Cam pinas, 78-79.

CAMARGO A.P. de, 1975. Apontamentos de meteorologia. Pinhal, Fundação Pinhalense de Ensino (nimeografado). 
CANNEL, M.G.R., 1983. Plant management in agroferestry: manipulation of trees, population densities and mixtures of trees and herbaceous crop. In: Huxley, P.A. Plant Research and Agroforestry: Proceedings of a Consultative Meeting. Nairobi.ICRAF.,p. 455-487.

CARD, 'F.W., 1897. Windbreaks. Bulletin of the U.S. Agric. Exp. Station of Nebraska, 48: 68-96.

CARDAN - a break for windbreaks, 1980. Soil Cons., 45 (8) : 11.

CHID, R. \& A.N. SMITH, 1960. Manganese toxicity in Grevillea robusta . Nature, London, $186(4730)$ (1067)

CORREA, M.P., (1926) Dicionário das Plantas üteis do Brasil e das Exōticas Cultivadas. Rio de Janeiro, Serviço de Informação Agrícola. v. 3 , p. 490-491.

DAVIS, R.M., 1976. Great Plains windbreak history: an overview. Iri: TINUS, R.W., Ed., Shelterbelts on the Great Plains; Proceedings of the Symposium. Denver, Great Plains Agricultural Council, p. 8-1l.

DENEKE, H., 1931. Uber den enfluss bewwegter luft auf die Kohlensăureassimilation. Jahr. wiss. bot. 74: 1-32.

DIMITROV, K.H. e P. KUKULAROV, 1977. MOisture retention of leached cher nozens under the influence of shelterbelts, and its effect on the yield of the agricultural crops. Gorkostopanska Nauka, Bulgária, 14 (5) : 25-32.

DZHODZHOV, K.H. e G.S. GEORGIEV, 1980. The protective action of a single shelterbelt against wind erosion. Gorkostopanska Nauka, Bulgá ria, 17(1): 60-64. 
EATON, H.J., 1971. Shelter belts and helges. Agriculture, 78 (5): 185 189.

FAO, 1956. Tree planting practices in Tropical Africa. Forestry Dev. Paper, Rorne, 8: 130-i32.

FERBER, A.E., 1958. Windbreaks in Conservation Farning. Washington , USDA Soil Cons. Serv. 22p. (Miscelaneous Publication, 759).

FERREIRA, L.A.B.; A.E.MAIXNER e N.H. TATSCH, 1976. Quebra-ventos arbóreos. Trigo e soja, Porto Alegre. 17: 13-15.

FINNEI, H.H. 1928. Effect of wind on plant growth. Journal of American Society of Agronorry. 20: 1206-1210.

FRANK, A.B.; D.G.HARRIS e W.O. WIILIS, 1974. Windbreak influence on water relations, growth and yield of soybeans. Crop Sci. 14:761765 .

GOITIA, D., 1956. Utilización de arboles forestales en "Cortinas Rompevientos". Bol. "Forestal, Bolívia, l: 49-5l.

GOLDSMITH, I., 1976. Action needed do discourage removal of trees that shelter cropland in the Great Plains. In: TIiUS, R.W., Ed. ,Shelterbelts on the Great Plains: Proceedings of the Symposium. Denver, Great Plains Agricultural Council, p. 12-18.

GOMES, A.L., 1972. Corttinas de protecção contra os ventos. Nova Lisboa, . IIAA. 15p. (Série Técnica, 29).

GREB, B.W. e A.L. BIACK, 1961. Effects of windbreak plantings on adjacent crops. J. Soil and water Cons. 16: 223-227. 
GRIFFITH, P.W., 1976. Introduction of the problems. In: T'INUS, R.W., Ed., Shelterbelts on the Great Plains: Proceedings of the Symposium. Denver, Great Plains Agricultural Councìl, p. 3-7.

GURGEL FILHO, O.A., 1969. Quebra-ventos protegen lavouras. Coopercoitia. $26(233): 21-22$.

GUYOT, G., 1963. Les brise-vent - Modification des microclimats et ame- lioration de la production agricole. Ann. Agron. Paris. 14(4): 429488.

HAGEN, L.J., 1976. Windbreak design for optimum wind erosion control. In: TINUS, R.W., Ed., Shelterbelts on the Great Plains: Proceedings of the Symposium. Denver, Great Plains Agricultural Council, p. 31-36.

HANSON, C.L. e F. RAUZI, 1977. Class A pan evaporation as affected Dy shelter, and-a daily prediction equation. Agricultural Meteorology. 18. (I) : 27-35.

HAVERBEKE, D.F. van, 1977. Conifers for single-row field windbreaks . USDA Forest Service. 10p. (Research Paper RM-196).

IBARRA, J.C., (s.d.). Antecedentes sobre la erosion, su evaluacion y control en Chile. Santiago, Depto. de Conservación del Medio Ambiente, (Publicaciōn no 11).

IBC, 1981. Cultura do café no Brasil. Rio de Janeiro, p. 212-215.

JEMISON, G.M., 1934. Beaufort scale of wind force as adapted for use on forested areas of the Northern Rocky Mountains.Jour Agric. Res. 49 (1): 77-82.

KOSCINSKI, M., 1938. Grevillea robusta. São Paulo, Directoria de Publici dade Agricola. 2lp. (Boletim de Agricultura, 39). 
KUMMERLY, W., 1974. El gran libro del bosque. Barcelona, Blume. 297p.

LEYTON, L., 1983. Crop water use: principle and some considerations for agroforestry. In: HUXLEY, PA. Plant Research and Agroforestry: Proceedings of a Consultative Meeting. Nairobi, ICRAF. p. 379-400.

LYLES, L., 1976. Wind pattems and soil erosion on the Great Plains. In: TINUS, R.W., Ed., Shelterbelts on the Great Plains: Proceedings of the Symposium. Denver, Great Plains Agricultural Council, p. 22-30.

MC CALL, W.E.; G.T. SHIGEURA E Y. N. TAMIMI., 1970. Windbreaks for Hawaii. University of Hawaii, Coop. Ext. Service. 10p. (Circular 438).

MELLO, H. do A., 1959. Ensaio de espaçamento com Grevillea robusta A. - Cunn. Revista de Agricultura. 34 (4): 267-272.

MULIER, D.R.; N.J. ROSENBERG e W.T. BAGTEY, 1973. Soybean water use in the shelter of a slat-fence windbreak. Agricultural feteorologv. 11: 405-418.

MORAIS, E., 1982. Fenologia do florescimento e frutificação da Grevillea robusta A. Cunn nas condições de São Simão, São Paulo. Piracicaba, ESALQ-USP. (mimeografado) $6 \mathrm{p}$.

NATIONAL ACADEMY OF SCIENCES, 1980. Firewood crops. Washington. National Academy Press. p. 86-87.

NIMER, E., 1979. Climatologia do Brasil. Rio de Janeiro, Fundação IBGESUPREN. 421 p. (Série Recursos Naturais e Meio Ambiente. 4).

CMETIO, J.C. e CARAMORI, P.H., 1981. Características do vento e suas im plicações em algumas plantas. In: Congresso Brasileiro de Agrometeorologia, 2. Resumos dos trabalhos apresentados nâs sessões técnicas. Pelotas, p. 260-267.

O'ROURKE, T.P., 1976. Tree planting: when in doubt, ask a forester. Forest and Timber, Canberra, $12(3): 4-5$. 
OPMAN, R., 1976. Design is the key to effective windbreaks.

Forest and Timber, Canberra, 12(3) 6-8.

OZOLIN, G.P. e I.M. TOROKHTUN, 1978. Povyshat' êffektivnost' pole zash chitnykt lesnyk polos. Lesnce Khozyaẽstvo, 7: 39-45.

PEITION, W.L., 1976. Windbreak studies on the Canadin prairie. In: TINUS, R.W., Ed., Shelterbelts on the Great Plains: Proceedings of the Symposium. Denver, Great Plains Agricultural Council, p. 64-68.

POTTER, B.G., 1976. The "Dirty Thirties" Shelterbelt Project. American Forests, 82 (1) 36-39.

RADKE, J.K., 1976. The use of annual wind barriers for protecting rowcrops. In: TINUS, R.W., Ed., Shelterbelts on the Great Plains. Proceedings of the Symposium. Denver, Great Plains Agricultural Council, p. 79-86.

RADKE, J.K. e W.C. BURROWS, 1970. Soybean Plant Response to Temporary Field Windbreaks. Agronomy Journal, 62: 424-429.

RADVANYI, J., 1978. Quelques aspects de la conception des bandes forestières de production dans les steppes soviétiques. Revue Forestère. Française, $30(6)$ : 489-496.

REDDY, C.V.K., 1979. Shelter belts against storms and cyclones on the coast. Indian Forester, 105(10): 720-725.

ROSENBERG, N.J., 1965. Microclimate, air mixing and physiological regulation of transpiration as influenced by wind shelter in an irrigated bean field. Agr. Meteor., 3: 197-224. 
ROSENBERG, N.J., 1976, Effects of windbreaks on the microclimate, energy balance and water use efficiency of crops growing on the Great Plains. In: TINUS, R.W., Ed., Shelterbelts on the Great Plains. Procedings of the Symposium. Denver, Great Plains Agricultural Council. p. $49-56$.

SCHIEBER, E. e G.A. ZENTMMER, 1978. An important canker disease of Grevillea in Guatemala. Plant Disease Reporter, 62 (10): 923-9.24.

SEGUIN, B. e N. GIGNOUX, 1974. Etude experimentale de l'influence d'un reseau de brise-vent sur le profil vertical de vitesse du vent. Agricultural Meteorology, 13: 15-23.

SEREDINA, M.A. e L.O. KARPACHEVSKII, 1982. Relationship between differentiation of trees and soil moisture-content regime in a shelter belt. Moscow Univ. Soil Science Bulletin, 37 (1): 53-55.

SIDDOWAY, F.H., 1970. Barriers for wind erosion control and water conser vation. Joumal of Soil and Water Conservation, 25 (5): 180-184.

SKIDMORE, E.L., 1976. Barrier-induced microclinate and its influence on growth and yield of winter wheat. In: ITNUS, R.W., Ed., Shelterbelts. on the Great Plain. Proceedings of the Symposium. Denver, Great Plains Agricultural council, p. 57-63.

SMITH, A.N., 1960. Boron deficiency in Grevillea robusta. Nature, London, 186 (4729) (987).

STAPIE, W.J. e J.J. IEHANE, 1955. The influence of field shelterbelts on wind velocity, evaporation, soil moisture and crop yield. Canadian Journal of Agri. Sci., 35: 440-453. 
STOECKEIER, J.H., 1963. Shelterbelts and their effects on crop yields in the Great Plains. Joumal of Soil and Water Conservation, 18(4) : $139-144$.

STURROCK, J.W., 1977. Shelterbelts in New Zealand - Experience and inno vation. Span, $20(3)$ : 118-120.

TIGRE, C.B., 1972. Quebra-ventos e faixas de proteção para a zona seca. Fortaleza, Ceará, DNOCS. 34p."

TKATCHENKO, B., 1950. Dëfense contre la sécheresse et contre l'erosion dans les steppes de la Russie méridionale. L'Agrononie Tropicale, 5: $3-41$.

TRENK, F.B., 1914. Shelterbelts for windblown soils. Agric. Ext. Serv. - of the College of Agriculture of the University of Wisconsin. 8p.

UJAH, J.E. e K.B. ADEOYE, 1984. Effects of the shelterbelts in the sudan savanna zone of Nigeria on microclimate and yield of millet . Agricultural and Forest Meteorology, 33(2/3): 99-107.

\section{$\therefore$}

VAN DEUSEN, J.L., 1978. Shelterbelts on the Great Plains: what's happe ning? Joumal of Forestry, 76(3): 160-161.

VIANA, A.S.; A.P. de CAMARGO e D.R. FERNANDES, 1978. Estudo de espaça mentos de quebra-ventos temporärios para café en formação. In: Anais. do Congresso Brasileiro de Pesquisas Cafeeiras. Ribeirão Preto, IBC. vol. 6, p. 42-45.

VORA, A.B.; A.J. PARAPILIIL e K.S. SHARMA, 1982. Effect of windbreak and shelterbelts on wheat and mustard as well as on wind velocity. Indian Forester, 108(3): 215-220 
WADSWORTH, R.M., 1959. An optimum wind speed for plant growth. Annals. of Botany, N.S., 23(89): 195-199.

WALKER, J., 1946. Planning and planting field shelterbelts. Dominion of Canada - Department of Agriculture. 15p. (Publication 785, Fanmer's Bulletin, 139).

WEAVER, J.E. e F.E. CLEMENTS, 1950. Ecologia Vegetal. Buenos Aires, Ed. Acme Agency . 6660.

WIIJEY, R.W., 1975. The use of shade in coffee, cocoa and tea. Horticultural Abstracts, $45(12)$ : 791-798.

WILIIS, W.O.; A.B. FRANK; E.J. GEORGE e H.J. HAAS, 1976. Soil water extraction by, and growth of multi-row windbreaks. In: TINUS, R.W.,Ed., Shelterbelts on the Great Plains.Proceedings of the Symposium. Denver, Great Plains Agricultural Council, p. 87-92.

WONG Jr., W.H.C., 1974. Grevillea robusta A. Cumn. In: Seeds of wood Plants in the United States. USDA For. Serv. Agric. Hand book. (450) : $437-438$.

WOODRUFF, N.P.; D.W. FRYREAR e L. LYLES, 1963. Reducing wind velocity with field shelterbelts. Manhattan, Agricultural Experiment Station, Kansas States University of Agriculture and Applied Science. 26 p. (Kansas Technical Bulletin, 131).

WOODRUFE, N.P.; R.A.READ e W.S. CHEPIL, 1959. Influence of a field windbreak on summer wind movement and air temperature. Manhattan, Agricultural Exp. Station, Kansas State University of Agriculture and applied Science. 24p. (Kansas Technical Bulletin 100).

WOODRUEF, N.P. e A.W. ZING, 1953. Wind tunnel studies of shelterbelt mo dels. Journal of Forestry, 51(3): 173-178. 
7. $A P E N D I C E$

7.1. Anālise Física do Latossol Roxo

\% de Unidade

\begin{tabular}{|c|c|c|c|c|c|c|}
\hline PROF. DO & 0,1 & & N S $\approx 0$ & & r) & 15,0 \\
\hline SOLO & (C.C.) & 0,3 & 1,0 & 3,0 & 6,0 & (PMP) \\
\hline $0-20 \mathrm{~cm}$ & 33,1 & 30,5 & 28,1 & 26,5 & 25,5 & 23,3 \\
\hline $60-80 \mathrm{~cm}$ & 33,9 & 30,6 & 28,4 & 27,1 & 27,1 & 24,8 \\
\hline
\end{tabular}

7.2. Dados de Velocidade Absoluta do vento

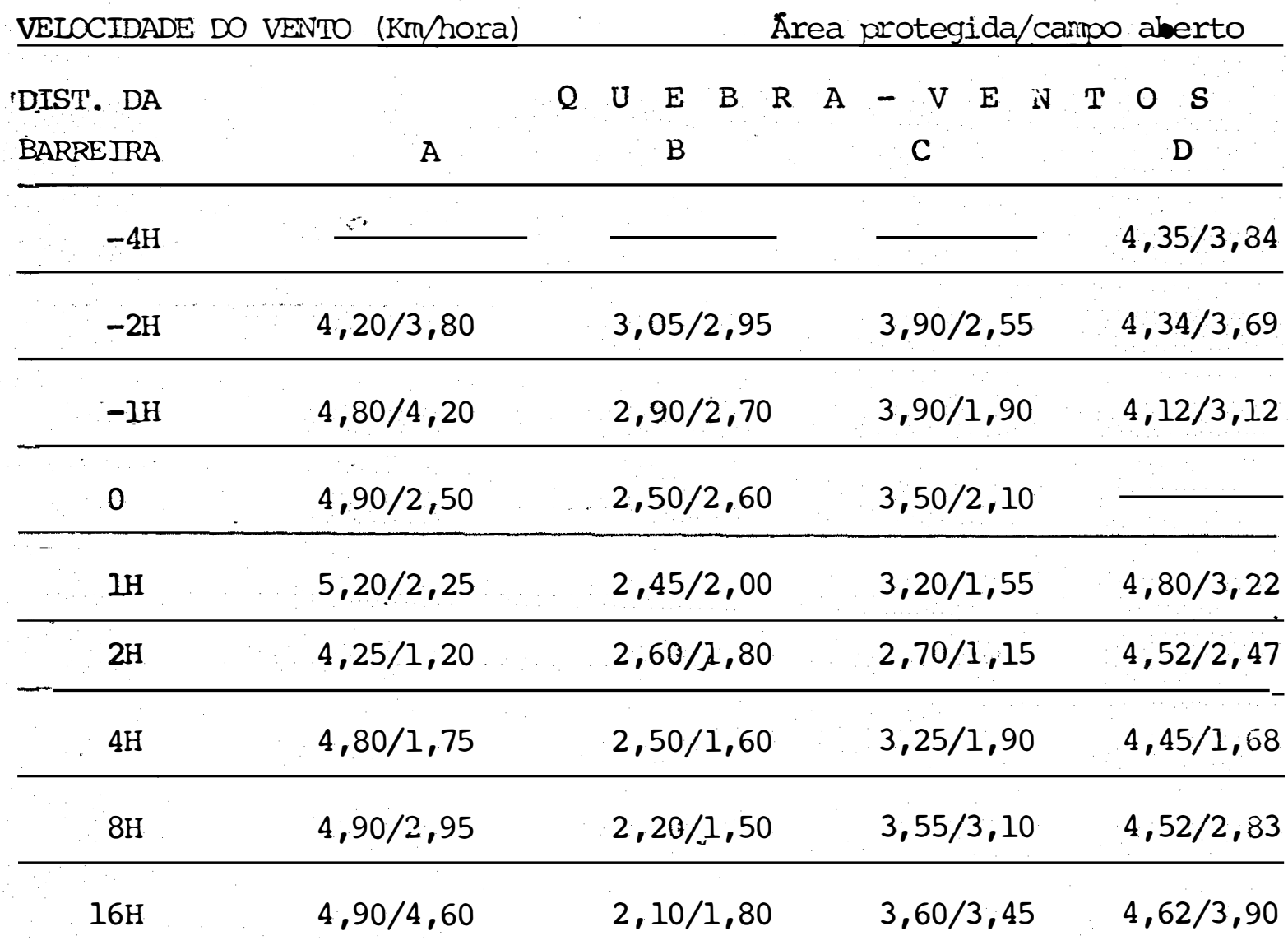




\subsection{DIMENSCES DO CAFEEIRO}

ALTURA (m)

\begin{tabular}{|c|c|c|c|c|c|c|c|c|}
\hline BARREIRA & $\therefore$ & II & III & IV & $\mathrm{V}$ & $\bar{X}$ & 5 & $\mathrm{CV} \%$ \\
\hline 0 & 2,50 & 2,30 & 2,30 & 2,20 & 2,70 & 2,40 & 0,20 & 8,3 \\
\hline$I H$ & 2,30 & 2,40 & 2,40 & 2,50 & 2,25 & 2,37 & 0,10 & 4,1 \\
\hline $2 \mathrm{H}$ & 2,65 & 2,35 & 2,60 & 2,40 & 2,50 & 2,50 & 0,13 & 5,1 \\
\hline $4 \mathrm{H}$ & 2,10 & 2,50 & 2,40 & 2,80 & 2,80 & 2,52 & 0,29 & 11,7 \\
\hline $8 \mathrm{H}$ & 2,50 & 2,20 & 2,55 & 2,15 & 2,45 & 2,37 & 0,18 & 7,7 \\
\hline $16 \mathrm{H}$ & 2,60 & 1,90 & 2,60 & 2,30 & 2,60 & 2,40 & 0,31 & 12,8 \\
\hline
\end{tabular}

DIÂMEIRO DA COPA (m)

DIST. DA

BARREIRA

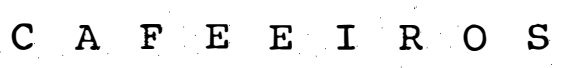

I II III IV V $\bar{X}$ S CV

\begin{tabular}{ccccccccccc}
\hline 0 & & 2,50 & 1,80 & 2,00 & 2,20 & 2,10 & 2,12 & 0,26 & 12,2 \\
\hline $1 \mathrm{H}$ & 2,70 & 2,60 & 2,30 & 2,70 & 2,80 & 2,62 & 0,19 & 7,3 \\
\hline $2 \mathrm{H}$ & 2,70 & 2,70 & 2,80 & 2,60 & 2,72 & 2,72 & 0,08 & 3,1 \\
\hline $4 \mathrm{H}$ & 2,20 & 2,70 & 2,40 & 3,00 & 2,60 & 2,58 & 0,30 & 11,8 \\
\hline $8 \mathrm{H}$ & 2,60 & 2,60 & 2,50 & 2,20 & 2,40 & 2,46 & 0,17 & 6,8 \\
\hline $16 \mathrm{H}$ & 2,40 & 2,30 & 2,70 & 2,50 & 2,50 & 2,48 & 0,15 & 5,9 \\
\hline
\end{tabular}


7.4. UMTDADE DO SOLO - \& DO PESO SECO

$0-10 \mathrm{~cm}$

DISTÂNCIA DA

$A M O S T$ R A S

BARREIRA

. A B C

C $\overline{\mathrm{x}}$

s

C.V. 8

\begin{tabular}{rrrrrrrr}
\hline OH & 25,6 & 25,8 & 25,1 & 25,5 & 0,36 & 1,4 \\
\hline $1 \mathrm{H}$ & 26,3 & 26,6 & 26,7 & 26,5 & 0,21 & 0,0 \\
\hline $2 \mathrm{H}$ & 26,4 & 26,9 & 27,1 & 26,8 & 0,36 & 1,3 \\
\hline $4 \mathrm{H}$ & 27,2 & 27,7 & 27,2 & 27,4 & 0,29 & 1,1 \\
\hline $8 \mathrm{H}$ & 26,9 & 27,6 & 27,6 & 27,4 & 0,40 & 1,5 \\
\hline $16 \mathrm{H}$ & 26,5 & 26,4 & 26,4 & 26,4 & 0,06 & 0,2 \\
\hline Campo aberto & 26,6 & 25,8 & 25,9 & 26,1 & 0,44 & 1,7 \\
\hline
\end{tabular}

$30-40 \mathrm{~cm}$

DISTÂNCIA DA

BARREIRA

A

B

C

$\bar{X}$

s

C.V. 8

\begin{tabular}{ccccccc}
\hline 0 & 30,2 & 29,9 & 31,1 & 30,4 & 0,62 & 2,1 \\
\hline $1 \mathrm{H}$ & 32,5 & 32,6 & 32,0 & 32,4 & 0,32 & 1,0 \\
\hline $2 \mathrm{H}$ & 33,3 & 33,8 & 33,7 & 33,6 & 0,26 & 0,8 \\
\hline $4 \mathrm{H}$ & 35,0 & 35,5 & 35,1 & 35,2 & 0,26 & 0,8 \\
\hline $8 \mathrm{H}$ & 34,8 & 34,2 & 35,0 & 34,7 & 0,42 & 1,2 \\
\hline $16 \mathrm{H}$ & 34,3 & 33,9 & 34,0 & 34,1 & 0,21 & 0,6 \\
\hline Canmpo Aberto & 33,2 & 33,0 & 33,4 & 33,2 & 0,20 & 0,6 \\
\hline
\end{tabular}


7.5. ANALLISE ESTATISTICA DOS RESUITADOS

Teste de Kruskal-Wallis, para dados não paramêtricos (CAMPOS, 1979)

UMIDADE DO SOLO: 0 a $10^{\circ} \mathrm{cm}$ de profundidade

\begin{tabular}{llll}
\hline $\begin{array}{l}\text { DIST. DA } \\
\text { BARREIRA }\end{array}$ & $\overline{U R}$ & $\overline{\mathrm{WD}}$ & \\
\hline 0 & 25,5 & 23,5 & $\mathrm{~b}$ \\
\hline $\mathrm{IH}$ & 26,5 & 33,7 & $\mathrm{a}, \mathrm{b}$ \\
\hline $2 \mathrm{H}$ & 26,8 & 36,7 & $\mathrm{a}, \mathrm{b}$ \\
\hline $4 \mathrm{H}$ & 27,4 & 42,4 & $\mathrm{a}$ \\
\hline $8 \mathrm{H}$ & 27,4 & 42,9 & $\mathrm{a}$ \\
\hline $16 \mathrm{H}$ & 26,4 & 32,7 & $\mathrm{a}, \mathrm{b}$ \\
\hline Campo aberto & 26,1 & 29,6 & $\mathrm{a}, \mathrm{b}$ \\
\hline
\end{tabular}

:UMIDADE DO SOLO: 30 a $40 \mathrm{~cm}$ de profundidade

\begin{tabular}{llcc}
\hline $\begin{array}{l}\text { DIST. DA } \\
\text { BARREIRA }\end{array}$ & $\overline{\mathrm{UR}}$ & $\overline{\mathrm{UD}}$ & \\
\hline 0 & 30,4 & 52,9 & $\mathrm{c}$ \\
\hline $\mathrm{IH}$ & 32,4 & 52,9 & $\mathrm{~b}, \mathrm{c}$ \\
\hline $2 \mathrm{H}$ & 33,6 & 84,3 & $\mathrm{a}, \mathrm{b}, \mathrm{c}$ \\
\hline $4 \mathrm{H}$ & 35,2 & 100,0 & $\mathrm{a}$ \\
\hline $8 \mathrm{H}$ & 34,7 & 95,1 & $\mathrm{a}, \mathrm{b}$ \\
\hline $16 \mathrm{H}$ & 34,1 & 89,2 & $\mathrm{a}, \mathrm{b}, \mathrm{c}$ \\
\hline $\mathrm{Cam}$ & 33,2 & 80,4 & $\mathrm{a}, \mathrm{b}, \mathrm{c}$ \\
\hline
\end{tabular}


As medidas seguidas pela mesma letra não diferem significativamente entre si.

PRODUTIVIDADE DOS CAFEEIROS

Para a produtividade dos cafeeiros o teste de Kruskal Wallis aponta diferença significativa entre as amostras, mas não é possível detectar diferença entre as mëdias de produtividade correspondentes a cada distância.

o alto coeficiente de variação $(C \cdot V$.$) encontrado é deoor-$ rente de änostragem insuficiente.

Segundo a fómula de COCiRAll (1965):

$$
n=\frac{t^{2} s^{2} \quad l-f}{d^{2}}
$$

onde: $n=n 8$ mínimo de amostras

$t=$ valor de tabela (Student)

$s^{2}=$ variância

$d=0,1$

$\mathrm{E}=\frac{\mathrm{a}}{\mathrm{N}}$

$\mathrm{a}=\mathrm{n} 8$ de amostras tomadas

$\mathrm{N}=\mathrm{n} \boldsymbol{8}$ total de individuos,

- número mínimo de amostras para cada distância seria de 76 ao nível de $5 \%$ de probabilidade e, ao nível de 1\%, 305 arnostras.

CAMPOS, H. de, 1979 Estatística Experimental não paramétrica, 3a. ed. , Depto. de Matenática e Estatỉstica - ESALQ. Piracicaba. 343p.

Cochran, W.G., 1965. Técnicas de amostragen. 2a. ed. Ed. Fundo de Cultu ra. Rio de Janeiro. 555p. 